\title{
Financial Development and Financial Liberalization in Asia: Thresholds, Institutions and the Sequence of Liberalization
}

\author{
By \\ Hiro Ito* \\ Portland State University
}

June 20, 2005

\begin{abstract}
I investigate whether financial openness leads to financial development after controlling for the level of legal/institutional development, and whether trade opening is a precondition for financial opening, focusing on Asia. Utilizing a panel encompassing 87 less developed countries over the period 1980 to 2000, I find that a higher level of financial openness spurs equity market development only if a threshold level of legal development has been attained, a condition prevalent particularly among emerging market Asian countries. On the issue of sequencing, trade openness is found to be a prerequisite for successful inducement of financial development via capital account liberalization.
\end{abstract}

JEL Classification: F36, F43, G28

Keywords: financial development, capital controls, financial liberalization, legal institutions, sequence of liberalization

\footnotetext{
${ }^{*}$ Corresponding author: Hiro Ito, Department of Economics, Cramer Hall 241, 1721 SW Broadway, Portland State University, Portland, OR 97201. Email: ito@pdx.edu .
} 


\section{Introduction}

The Asian crisis of 1997-98 confronted policy makers with the conundrum of financial globalization. While more open financial markets can contribute to economic development, it is the openness of financial markets that can make developing countries more vulnerable to financial disruptions (Kaminsky and Schmukler, 2001a,b, 2002 and Schmukler 2003). ${ }^{1}$

Despite the experience of the 1990's, East Asian policy makers do not appear to have abandoned the path of financial liberalization. Rather, as is best exemplified by the Chiang Mai Initiative, they have re-emphasized economic development through more integrated financial markets in the region. The progress in financial development has occurred against a backdrop of regional trade arrangements. As Pomfret (2005) documents, the Asian currency union also started being discussed in the region, signifying the importance of how to sequence liberalization policies. ${ }^{2}$ In sum, the debate is not whether to liberalize, but that of how to liberalize. This study attempts to inform that debate.

A common view is that capital account liberalization leads to the development of financial markets that channel funds to borrowers with the most productive investment opportunities. ${ }^{3}$ Theory suggests several mechanisms for this occurrence. First, financial liberalization may mitigate financial repression in protected financial markets, allowing the real interest rate to rise to its competitive market equilibrium (McKinnon, 1973; Shaw, 1973). Second, the removal of capital controls allows domestic and foreign investors to engage in more portfolio diversification, thereby reducing the cost of capital, and increasing the availability of funds. ${ }^{4}$ Third, and not least, the liberalization process usually increases the efficiency of the financial system by weeding out inefficient financial institutions and creating greater pressure for a reform of the financial infrastructure, alleviating information asymmetry issues such as adverse selection and moral

\footnotetext{
${ }^{1}$ In this study I do not discuss the merits of capital controls in the context of financial crises. For a review, see Aizenman (2002). Kletzer and Mody (2000) survey the debate in the context of “self-protection policies” for emerging markets. Ito (2004) investigates the correlation between financial liberalization and the output performance of crisis-hit economies.

${ }^{2}$ See Eichengreen (2004) for the arguments about the ingredients for the Asian currency union.

${ }^{3}$ See for instance Leahy, et al. (2001) for OECD-specific results. Klein and Olivei (2001) document the linkage between financial development and economic growth for developed countries, and its absence for less developed countries. Spiegel (2001) examines an APEC sample, while Arteta, Eichengreen and Wyplosz (2001) document the fragility of many of these group-specific results. IMF (2001, Chapter 4) surveys both the growth and finance, and finance and liberalization literatures. For the most recent review on finance and growth, refer to Quinn, et al. (2002) ${ }^{4}$ See Shultz (1999), Henry (2000), and Bekaert et al.(2000, 2001).
} 
hazard (Claesens et al., 2001; Stulz, 1999; Stiglitz 2000).

The link between financial liberalization and financial development is not unambiguous, however. One common argument is that to benefit from more open cross-border financial transactions, financial systems need to be equipped with reasonable legal and institutional infrastructure. ${ }^{5}$ Specifically, in economies where the legal system does not clearly define property rights or guarantee the enforcement of contracts, the incentives for loan activities can be limited. Legal protections for creditors and the level of credibility and transparency of accounting rules are also likely to affect economic agents’ financial decisions. ${ }^{6}$ La Porta, Lopez-de-Silanes, Shleifer, and Vishny (hereafter LLSV, 1997, 1998) and Levine $(1998,2002)$ show that low levels of shareholder rights are associated with poorly developed equity markets (especially in French civil law countries), while Claessens, et al. (2002) and Caprio, et al. (2004) find that greater creditor rights are positively associated with financial intermediary development.

The ambiguity can be empirically reconciled by incorporating explicitly the level of legal and institutional development. I hypothesize that financial liberalization can lead to financial development only if the economic system is equipped with a reasonable level of legal and institutional development.

In this paper, I also examine another oft-discussed issue related to the sequence of liberalization, that is, the order of liberalization in goods and financial markets. The prominent work by McKinnon (1991) argues that liberalization in the trade sector must precede liberalization in the capital account transactions. Rajan and Zingales (2003) argue that financial liberalization can lead to financial development only when the economy is open in both cross-border trade and capital flows because the economic openness can lead to weakening the political power of incumbent financial institutions to oppose further financial development. Aizenman and Noy (2004), while investigating countries' motivations for capital controls, find that financial openness and trade openness are bidirectional though the causality from the former to the latter is found to be more pervasive than the other. Given the ongoing debates over the manner in which to implement financial and real integration in Asia, I think this question is of central importance.

\footnotetext{
${ }^{5}$ Klein (2005) documents the presence of nonlinearities in growth effects of capital account liberalizations.

${ }^{6}$ For the analysis of legal development on financial development, see Beck and Levine (2004), Claessens, et al. (2002), Caprio, et al. (2003), and Johnson, et al. (2002). For a general discussion on the importance of legal and institutional foundations for financial development, see Beim and Calomiris (2001).
} 
This paper conducts a panel data analysis using the dataset encompassing 87 developing and emerging market countries (including 15 Asian countries) and twenty years ranging from 1980 to 2000. In the econometric analysis, I pay special attention to financial development in the equity market sector and attempt to highlight any special attributes of the Asian region.

The empirical results suggest that a higher level of financial openness contributes to the development of equity markets, but only if a country is equipped with a certain level of legal and institutional development. This finding is applicable not only to the group of less developed countries in general, but also to that of the Asian economies. It can be further surmised that many of the Asian emerging market countries have been more successful in reaping the benefits of financial liberalization because of their relatively higher levels of legal and institutional development. Higher levels of bureaucratic quality, and of law and order, as well as the lower levels of corruption, have enhanced the effects of financial opening in fostering the development of equity markets for less developed countries in general, while only the absence of corruption and a high index of law and order matter for the Asian countries. As for the issue of the sequencing, the liberalization in cross-border goods transactions is found to be a precondition for capital account liberalization among all the sample groups. When the endogeneity of financial openness is accounted for using trade openness as an instrument, it is confirmed that financial liberalization leads to financial development.

\section{Overview of Financial Development and Financial Openness in Asia}

First, I take an overview of the development of financial markets in less developed countries, focusing on the Asian economies. The original dataset includes 108 countries, out of which 22 are industrialized countries (IDC), 87 less developed countries (LDC), and 15 Asian countries (ASIA). ${ }^{7}$ See Appendix 1 for the composition of the sample.

\subsection{Financial Development in Asia}

\footnotetext{
${ }^{7}$ There is also a subgroup of emerging market countries, EMG. The definition of this group relies upon the International Financial Corporation's (IFC) indices, and refers to the countries which were included in either IFC's Global, Investible, or Frontier Index as of 1995. By this definition, there are 31 EMG countries in our sample. The Asian subgroup does not include Japan. Asian EMG refers to the Asian countries that are also categorized as EMG.
} 
Drawing on the work of Beck, Demirgüc-Kunt, and Levine (2000), I use the following four financial development variables (FD). PCGDP, the ratio of private credit from deposit money banks to the private sector, represents the overall development in private banking markets. While this variable is examined for purposes of comparison, the primary focus is placed on the development of equity markets development, for which three variables are used as the measures: SMKC (stock market capitalization), SMTV (total value of stocks traded), and SMTO (stock market turn over ratio). SMKC can be considered as the measure of the size of equity markets and SMTV and SMTO as the measure of the activeness of equity markets. ${ }^{8}$

Figures 1(a)-(d) illustrate financial development measured in the above variables for different subsamples. In addition to IDC, LDC, and ASIA, I also have the subgroups of non-Asian less developed countries and Latin American countries for comparison purposes. These figures show that the Asian region historically achieved high level of financial development compared to other less developed countries. In fact, these countries' financial development has been as rigorous as industrialized countries in both banking and equity markets development. Also, its achievement during the 1990s is remarkable despite the Asian financial crisis.

Table 1 reports the growth rates of the financial development variables. Inspection of the table reveals that while during the 1990s, all subsample groups experienced the most rapid development in equity markets, measured along several dimensions, including size (SMKC) and transactions activity (SMTV and SMTO). This is true despite the retrenchment in the equity markets of less developed and emerging market countries during the second half of the decade. Again, despite the crisis, the speed of Asian financial development in recent years is striking.

\subsection{Financial Openness in Asia}

In this paper, the extent of financial openness is measured using the capital account openness index, KAOPEN developed by Chinn and Ito (2002). Many researchers have used binary variables based upon the IMF's categorical enumeration reported in Annual Report on Exchange

\footnotetext{
${ }^{8}$ In this study, I do not look into offshore markets as part of financial development, and therefore, focus merely on the development of domestic equity markets. Although we have witnessed that some Asian emerging market countries such as Korea and Thailand tried to complement their domestic markets by developing offshore markets and allowing foreign investors, mostly hedge funds, to actively engage, there have not developed so much literature regarding these issues, mainly owing to the recentness of the development of hedge funds and offshore markets (except for Fung and Hsieh, 2001; Brown and Goetzmann, 2001; and Brown et al., 1998). Furthermore, the relationship between onshore and offshore funds has not been rigorously investigated (except for Kim and Wei, 2002) due to data unavailability.
} 
Arrangements and Exchange Restrictions (AREAER) ${ }^{9}$ and others such as Quinn (1997) and Miniane (2004) have created more delicate measures. ${ }^{10}$ However, the consensus is that such measures fail to fully capture the complexity of real-world capital controls. ${ }^{11}$ KAOPEN is the first principle component of the four IMF binary variables, and higher values indicate greater financial openness.

One of the merits of the KAOPEN index is that it attempts to measure the intensity of capital controls, insofar as the intensity is correlated with the existence of other restrictions on international transactions. One may argue that the KAOPEN index measures the extensity of capital controls because it may not directly refer to the stringency of restrictions on cross-border transactions, but to the existence of different types of restrictions. However, measuring the extensity of capital controls may be a good proxy to the measure of intensity of capital controls. For example, considering that transactions on the current account have often been used to evade capital account controls (Edwards, 1999), policy makers can increase the stringency of capital controls by tightening transactions on the current account restrictions or other systems such as multiple exchange rates and requirements to surrender export proceeds. Another merit of this index is its wide coverage (more than 100 countries) for a long time period (1970 through 2000). Appendix 2 explains with more details how KAOPEN is constructed.

One more note must be made about this index. By the nature of its construction, this index is considered to be de jure measures on financial openness because it attempts to measure regulatory restrictions on capital account transactions. Hence, this index is different from price-based measures on financial openness, namely those based on the interest rate parity (UIP or

\footnotetext{
${ }^{9}$ These binary variables are created based on a set of "on-off” clarification, which includes an indicator variable for the existence of multiple exchange rates $\left(k_{1}\right)$; restrictions on current account $\left(k_{2}\right)$; capital account transactions $\left(k_{3}\right)$; and a variable indicating the requirement of the surrender of export proceeds $\left(k_{4}\right)$. $k_{3}$ is the one often used for capital controls. In 1996, the classification method in the AREAER changed and these four categories became more disaggregated as an effort to reflect the complexity of capital controls policies.

${ }^{10}$ The Quinn index is a composite measure of financial regulation and based upon Quinn's coding of the qualitative information contained in the AREAER pertaining to $k_{2}$ and $k_{3}$, augmented by information regarding whether the country in question has entered into international agreements with international organizations such as the OECD and EU. The Quinn index is available for the OECD members between 1958 and 1997, but the coverage for the less developed countries is limited to certain years (1958, 1973, 1982, 1988, and 1997). Johnston and Tamirisa (1998) created the time series of capital controls based on the recently created disaggregate components in the AREAER. However, the time series of the variables only covers years after 1996. Most recently, Miniane (2004) constructed a set of indices to measure the intensity of capital controls, based on an approach akin to Johnston et al., but extending the data back to 1983 for 34 countries.

${ }^{11}$ See Edison and Warnock (2001), Edwards (2001), and Edison et al. (2002) for discussions and comparisons of
} 
RIP) approach such as Cheung, et al. (2003) and Montiel (1995) or those on deviations from no arbitrage profits conditions such as De Gregorio (1998). Researchers often refer to these price-based measures as de facto measures on financial integration. These two types of financial openness measures have their own strengths and weaknesses. ${ }^{12}$ However, it is almost impossible not only to rank the supremacy of these measures, but also to distinguish them. Nonetheless, this paper focuses on regulatory aspects of capital account openness.

Table 2 presents the averages of KAOPEN for the full sample period of $1970-2000$ and each decade for different sample groups. Figure 2 shows the development of financial openness for the subgroup of Asia, non-Asian LDC, and Latin American countries. From the table and the figure, we can see that the Asian countries are different from other less developed countries in that these countries did not halt the efforts of financial liberalization during the 1980s while other less developed countries, especially Latin American countries, considerably restricted capital accounts during the decade. The Asian countries liberalized capital accounts rapidly in the first half of the 1990s until the occurrence of the Asian crisis, that led these countries to restrict capital accounts.

\section{An Econometric Analysis}

In what follows, I investigate the issues relevant to the sequence of liberalization.

\subsection{The Empirical Specification}

First, I will examine the long-term effect of capital account openness on financial development in a model that controls for the level of legal and institutional development. The model is specified as:

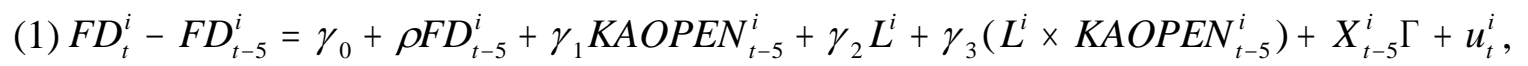

where FD is a measure of financial development; KAOPEN is a measure of financial openness; $\boldsymbol{X}$

various measures on capital restrictions.

${ }^{12}$ One of the drawbacks of de jure measures on financial openness is that as Edwards (1999) discusses, it is often the case that the private sector circumvents capital account restrictions, nullifying the expected effect of regulatory capital controls, which can be captured by price-based measures. A drawback of the price-based measures, on the other hand, is the measures, especially those based on the interest rate parity conditions, can reflect changes in macroeconomic conditions even if there is no regulatory changes on capital account transactions. For categorization of measures on financial integration and/or financial openness, refer to Cavoli, et al. (2003) and Takagi and Hirose (2004). 
is a vector of economic control variables; and $L^{i}$ refers to a measure of legal or institutional development.

The vector $\boldsymbol{X}$ contains macroeconomic control variables that include log per capita income in PPP terms, the inflation rate, and trade openness, measured as the ratio of the sum of exports and imports to GDP. In this analysis, the set is kept fairly small so as to retain some interpretability of the correlations. Log per capita income is included as there is a long literature ascribing financial deepening, aside from the role of regulation, to the increasig complexity of economic structures associated with rising income. The inflation rate is included because it may distort decisionmaking. ${ }^{13}$ In particular, moderate to high inflation may discourage financial intermediation, and encourage saving in real assets. Finally, trade openness is included as an ad hoc control; many empirical studies find a correlation of trade openness with any number of economic variables. The relationship between trade openness and financial openness will be investigated more thoroughly in a later section.

A series of regressions is conducted for each of the four financial development variables (FD): PCGDP, SMKC, SMTV, and SMTO. For the series of regressions with different financial development measures, I also include each of the four legal/institutional variables and its interactive term with the capital account openness index. Further discussions about the legal/institutional variables are presented in the data section.

In order to avoid problems of endogeneity associated with short-term cyclical effects, I specify the model as a growth rate on levels regression, akin to a panel error-correction model with non-overlapping data. That is, data are sampled only every five years between 1980 and 2000, and the five-year average growth of the level of financial development is used as the dependent variable and the "initial conditions" for time-variant explanatory variables, including the initial level of the financial development indicator, for each five-year panel. ${ }^{14}$ The regressions are conducted for 87 less developed and emerging market countries.

\subsection{The Data}

\footnotetext{
${ }^{13}$ Since in most cases, the volatility of inflation rises with the inflation rate, the inflation rate could be proxying for either or both of these effects.

${ }^{14}$ Time fixed effects are also included in the model to control for possible time-specific exogenous shocks.
} 
The data are originally recorded at an annual frequency, over the 1970-2000 period, covering 108 countries and drawn from a number of sources, primarily the World Bank's World Development Indicators, the IMF's International Financial Statistics, and the databases associated with Beck, Demirgüc-Kunt, and Levine (2000).

\section{Measures of Legal/Institutional Development}

The legal/institutional variables used in this study contain the measures related to the general development of legal systems and institutions, namely LEGAL1, Corrupt, $L A O$, and BQ. $L E G A L 1$ is the first principal component of the other three variables, and this variable is treated as a representative measure of the general level of legal/institutional development. ${ }^{15}$ Corrupt, LAO, and $B Q$ measure the level of corruption, law and order, and the quality of the bureaucratic system, respectively. All of these data series included in LEGAL1 are obtained from the ICRG database. In these indexes, higher values indicate better conditions. The data series are available for the period of 1984 through 1997, but are included as the period-average.

Before discussing the regression results, I make one observation. In the following panel data analyses, the data on legal/institutional development are cross-sectional in nature, i.e., they are time-invariant. The relative shortness of the time series of the ICRG variables makes it difficult to include these variables as panel data. As Wei (2000) discusses (on the corruption indices in his paper), these types of institutional variables may entail some possibility of biasness. In order to circumvent this issue, it is reasonable to use the period average. Also, the inclusion of these variables as time-invariant factors should not pose a substantial problem for this study, since these characteristics represented by the legal/institutional variables are likely to change only very slowly. ${ }^{16}$ Moreover, I focus mainly on the effect of financial openness on financial development, but not the effect of legal/institutional development per se. In other words, rather than shedding light on how the development of institutions and legal systems affects financial development, I examine how the effect of financial openness changes depending upon the "environment” of

\footnotetext{
${ }^{15}$ The first eigenvector for Legal1 was found to be (Corrupt, $\left.L A O, B Q\right)^{\prime}=(0.574,0.580,0.578)^{\prime}$, indicating that the variability of $L E G A L 1$ is not merely driven by any particular series.

${ }^{16}$ Stulz (1999) and Stiglitz (2000) argue that financial globalization puts pressure on governments to improve legal systems and infrastructure for financial markets. However, to my knowledge, there is no empirical evidence for the causality.
} 
institutions and legal systems. Therefore, time-variation of the legal/institutional variables is not critical to this study.

\subsection{Empirical Results}

The regression results for the model specified in equation (1) are reported in Tables 3-1 and 3-2. The estimated coefficients of focus are those of $K A O P E N_{t-5}$ (first row), the legal variable (second row), and the interactive term between the legal variable and $K A O P E N_{t-5}$ (third row). For each financial development variable, the regression results are shown for three sample groups: less development countries, Asian countries, and non-Asian less developed countries. ${ }^{17}$ The following observations will mainly focus on the regressions with equity market development measures; the regressions with stock market capitalization (SMKC) represent financial development in terms of the size of stock markets, and the ones with stock market total values (SMTV) represent the activeness of the equity markets. The results for the regressions with private credit creation (PCGDP) are presented for comparison purposes while those with stock market turnover (SMTO) are omitted because the role of the variable overlaps with SMTV.

Table 3-1 reports the regression results for the models with $L E G A L 1$. In the LDC sample, when financial development is measured by stock market total values, financial openness $\left(K A O P E N_{t-5}\right)$ contributes both directly and in an interactive manner with legal and institutional development to equity market development. In both the Asian and non-Asian LDC samples, the interactive effect between financial openness and legal development is detected. Significant coefficients for the interactive term are also found in the models with equity market development measured by stock market turnover for LDC and non-Asian LDC subsamples (not reported).

Here, one must be careful about how to interpret the overall effect of capital account openness because it depends on the level of legal development. ${ }^{18}$ That is, given equation (1), the total effect of financial openness can be shown as:

Total Effect of KA openness ${ }^{i}=\left(\gamma_{1}+\gamma_{3} \bar{L}\right) K A O P E N_{t-5}^{i}$,

where $\bar{L}$ is the mean of a measure of legal development. For example, when one examines the

\footnotetext{
${ }^{17}$ Since the sample size is small for the Asian subsample, the results for this group are treated as suggestive references.

${ }^{18}$ In case of the regressions with $L E G A L 1$, the fact that the variable can be negative for a lower value also contributes to the complexity in the interpretation.
} 
regression specifications for the financial development measured in stock market total value for LDC group in Table 3-1 (column [7]), the total effect of a one-unit increase in KAOPEN is calculated to be -0.06 percent point using the LDC group's average of $L E G A L 1,-0.74$. If the same calculation is conducted for the Asian group using the same coefficients from column [7] but the group's average of $L E G A L 1,-0.45$, the total effect is now 0.24 percent point because the Asian group's average of LEGAL1 is higher than LDC's. Thus, opening capital accounts can lead to a lower or higher rate of development in equity markets, depending upon the level of legal and institutional development.

Table 4 makes this point clear. In this table, row [A] shows the total effect of a one-unit increase in KAOPEN calculated using the estimates from the regression model with stock market total value for the LDC group, evaluated at the average values of the legal variable for each of the sample groups: Latin America, non-Asian LDC, LDC, ASIA, EMG, and Asian EMG (shown in row [B]). Row [C] shows the threshold level of the legal variable, above which a one-unit increase in capital account openness has a positive impact on equity market development. The table illustrates that, in order for capital account openness to contribute to the development of equity markets, countries must be possessed of a level of legal/institutional development greater than the threshold level of $L E G A L 1=-0.68$. Hence, among the sample groups, the groups of emerging market countries, Asian economies, and Asian emerging market countries (whose average values of LEGAL1 exceed the -0.68 threshold) will on average benefit from opening their capital accounts. On the other hand, less developed countries, non-Asian LDC, and the Latin American group will hamper their equity market development by opening capital accounts. Especially, the negative effect of financial opening on the Latin American group is significant because of the low level of legal and institutional development. The Asian emerging market countries, on the other hand, can develop equity markets considerably by opening their capital accounts.

As specific examples, Peru increased its financial openness from -1.84 to 2.27 between 1990 and 1995. Given its LEGAL1 level of -1.65 , much lower than the threshold of -0.68 , the increase in financial openness would reduce the growth rate of stock market total value by $4.1 \%$ point annually. Thailand, on the other hand, experienced a smaller increase of 1.10 in its KAOPEN variable (from 0.15 to 1.25 ), but because its $L E G A L 1$ level is 0.39 , much higher than the threshold as well as Peru's, its SMTV is predicted to grow at an additional $1.2 \%$ annually. Given that SMTV 
grew at $1.99 \%$ annually for less developed countries during the 1990s (Table 1), this acceleration in the growth rate is significant.

Figure 3 presents a visual picture of the total effect of an one-unit increase in KAOPEN based on each country's value of LEGAL1 for Asian and Latin American countries. The countries are placed in the order of the magnitude of the total effect of an one-unit increase in KAOPEN. The countries that have positive effects of financial opening are those which attained a threshold level of legal and institutional development such as Malaysia and Korea, whereas countries with underdeveloped institutional infrastructure may hamper equity market development.

Table 3-2 summarizes the results from the regressions that are run with each of the components of $L E G A L 1$ (i.e., Corrupt, $L A O$, and $B Q$ ) included individually and interactively. For the sake of brevity, the table shows only the coefficients of the financial openness variable, the legal/institutional variable, and the interaction term. For the group of less developed countries in general, across the different models with different measures of financial development, the significance of the estimated coefficients appears to be qualitatively the same as those of the regressions with $L E G A L 1{ }^{19}$ In the Asian subsample, when financial development is measured by stock market total values, both the level and interactive terms with KAOPEN are statistically significant for the models with Corrupt and LAO (and adjusted R-squares are relatively higher than other subgroups). Bureaucratic quality seems to matter for non-Asian less developed countries, but not for the Asian countries. Interestingly, the coefficient of $K A O P E N_{t-5}$ alone has a negative sign wherever the interactive term has a significant coefficient, suggesting that opening financial markets alone may lead to underdevelopment of equity markets, but it can be avoided only if the countries are equipped with a reasonable level of legal/institutional development.

Table 4, again, helps the interpretation of the overall effect of KAOPEN for the models with SMTV. Generally, liberalizing capital accounts lead to development in equity markets only when the measures against corruption or law and order are higher than the threshold levels (52.2 and 54.5, respectively). When the level of bureaucratic quality is controlled for, financial openness seems to leads to financial development among all subgroups except for Latin America. For the

\footnotetext{
${ }^{19}$ Although the coefficient of KAOPEN is negative in most of the cases when it is significant, this is because, unlike $L E G A L 1$, all the three legal/institutional variables in these models do not contain any negative values. However, because of the negative coefficients, the argument about the thresholds of legal/institutional variables is valid as was in the case of LEGAL1.
} 
Asian subgroup (column [4]), it appears that only the average level of bureaucracy quality is high enough for the countries in this group to reap from financial liberalization while that is not the case with the levels of anti-corruption and law and order. However, as far as Asian emerging market countries are concerned, all of these countries' levels of anti-corruption, law and order, and bureaucracy quality are high enough for them to benefit from financial liberalization. As such, I can conclude that it is the relatively higher levels of legal and institutional infrastructure that allow Asian countries, especially Asian emerging market countries, to reap the benefit from financial liberalization and develop their equity markets. This result is consistent with the observations from Tables 1 and 2.

The same exercise is repeated using a different set of legal and institutional variables. The new variables pertain particularly to financial transactions, namely, creditor protection (CREDITOR), contract enforcement (ENFORCE), shareholder protection (SHRIGHTS), and the accounting standards (ACCOUNT), all of which are obtained from $\operatorname{LLSV}(1997,1998)$. I also constructed a composite index LEGAL2 which is the first standardized principal component of the four variables, and therefore depicts the overall development of the legal system governing financial transactions. The regressions using $L E G A L 2$ as the legal/institutional variable yield qualitatively the same results as those with $L E G A L 1$. However, the results for the models with each of the four LLSV variables included as the legal variable are not as decisive as in the previous cases (not reported). ${ }^{20}$ These findings suggest that it is the development of general legal systems and institutions, not of those specific to financial transactions, that is crucial for a country to benefit from opening its capital accounts.

\subsection{Robustness Checks}

The above results are obtained from the estimation of a set of non-overlapping five-year panels, which has a merit of mitigating endogeneity problems. In addition, this estimation method has other advantages. First, it serves to minimize the effect of correlations due to business cycle fluctuations because it samples observations data every five years. Second, for the same reason, the use of five-year windows allows one to minimize (but does not completely solve) the effect of

\footnotetext{
${ }^{20}$ Due to the data availability of the LLSV variables, the sample of less developed countries is mostly composed of emerging market countries. For the same reason, the disaggregated regression analysis for the Asian or non-Asian LDC subgroups are not conducted.
} 
financial bubbles the financial development indicators may unintentionally capture. As a point of reference, it is useful to note that in many studies of lending booms as financial crises indicators, changes in lending or stock market sizes over a shorter window, of between 2 to 4 years are, often used. ${ }^{21}$ However, the choice of five years as the length of each window is still arbitrary. Hence, I conduct a series of robustness checks regarding the panel windows. In order to conserve space, I only summarize the results below.

First of all, I checked whether the estimation results are specific to the years from which data are sampled, i.e., 1980, 1985, 1990, 1995, and 2000. I reran the regressions using the non-overlapping data from the years one year before or after the above years (i.e., every five years starting in 1979 or 1981). The estimation results are found to be qualitatively unchanged. Second, I changed the length of the panel intervals. When the length of the windows is changed to four years as well as six years, the estimation results are qualitatively intact, though the estimation results become stronger in terms of the key coefficients' magnitude and significance when the length is changed to six years. ${ }^{22}$

I also examined whether the above baseline results are sensitive to outliers. It is important to check the impact of outliers because the data on financial development can be subject to financial bubbles as previously discussed, and also because they can involve some measurement errors. First, using the original annual data, I exclude the observations of financial development variables if their annual growth rates are two standard deviations away from the mean in both directions, and re-estimate the same sets of regressions. ${ }^{23}$ Generally, in the re-estimated results (not reported), the magnitude of the estimated coefficients often becomes smaller, but so do the standard errors, especially for the models with stock market related measures. Therefore, not only does the statistical significance of the coefficients remain qualitatively unchanged, but in addition some of

\footnotetext{
${ }^{21}$ See Corsetti, Pesenti, and Roubini (1998), Chinn, Dooley and Shrestha (1999), Kaminsky (2003), Kaminsky, Lizondo and Reinhart (1998), Kaminsky and Schmukler (2001b), and Sachs, Tornell and Velasco (1996).

${ }^{22}$ I also conducted the robustness checks by changing the length of the window for the SHARE variable (see Appendix 2) in the same way as that of the panel windows. When a new KAOPEN variable is calculated using a four-year or three-year window for the SHARE variable are used, the estimation results are found to be qualitatively fairly unaffected. When both the length of the window for the SHARE variable and the length of panel windows are changed in the same way, as long as the change is to either four or six years, the results did not change.

${ }^{23}$ This exercise was conducted only for the sample of less developed countries because the subsamples are small in the first place. The exclusion of outliers shrinks the sample size by about $0-11 \%$ and takes place more for the models with stock market total value and stock market turnover than those with private credit creation and stock market capitalization, which reflects that the former group are more subject to market volatility than the latter.
} 
the coefficients which were previously insignificant become significant. Interestingly, in many models the adjusted $R$-squared increases. ${ }^{24}$ These results allow me to conclude that the key findings of the analysis are not driven by outliers, and also that some of the findings related to the legal/institutional variables could have even been obscured by the effects of outliers.

\subsection{Reverse Causality?}

One may reasonably ask if financial development is what allows countries to implement financial liberalization policy, rather than the reverse. As has been discussed, non-overlapping, five-year panel analysis should mitigate problems associated with simultaneity, but it may still be worthwhile to investigate whether countries need to develop their financial systems before undertaking capital account liberalization. Conversely, if I can show that reverse causality is irrelevant, that will be evidence that countries can develop their financial markets by exogenously deciding to open their financial markets.

To explore the above question, I change the specification in equation (1) by exchanging the places of KAOPEN $N_{t-5}$ and financial development measures (PCGDP, SMKC, SMTV, and SMTO); the left-hand side variable is now the five-year average growth in KAOPEN while the independent variables of focus now becomes the financial development variable and the interactive terms between the legal/institutional variables and the financial development variables. I run regressions specified as follows, using non-overlapping data and including each of the legal/institutional variables:

(2) $K A O P E N_{t}^{i}-K_{A O P E N_{t-5}^{i}}=\phi_{0}+\varphi K A O P E N_{t-5}^{i}+\phi_{1} F D_{t-5}^{i}+\phi_{2} L^{i}+\phi_{3}\left(L^{i} \times F D_{t-5}^{i}\right)+X_{t-5}^{i} \Phi+v_{t}^{i}$.

The coefficient of interest is $\phi_{1}$; A significantly positive $\phi_{1}$ would indicate that the above OLS regression results entail simultaneous causality, i.e., financial development leads to financial openness. The regression results (not reported) show that across different sample groups and regressions with different financial development measures as well as legal/institutional variables, the coefficients, $\phi_{1}$ 's, are mostly statistically insignificant or significantly negative, either of

\footnotetext{
${ }^{24}$ The same exercise is then repeated, but increasing the range of outlier exclusion by dropping the observations if their annual growth rates are larger than one and a half standard deviations away from the mean in both directions. This exclusion shrinks the sample size quite substantially (sometimes as much as 40\%), although the results are largely unchanged or even improved.
} 
which is against the null hypothesis that financial development leads to financial openness. The significantly negative $\phi_{1}$ 's are found in the regressions that have the dependent variable of the equity market development measures. One of the possible explanations for the negative $\phi_{1}$ may be that a rapid growth in equity markets, in terms of the size of the markets (SMKC) or the liquidity of the markets (SMTV or SMTO) is sometimes associated with financial crises, and that policy makers lower the degree of financial openness during periods of crisis (Ito, 2004). At the very least, I can conclude that the baseline estimation results are not subject to obvious simultaneity issues (as in Bekaert, et al., 2001).

\section{Investigating the Sequence of Liberalization}

\subsection{Trade and Capital Account Liberalization}

The next question is whether trade openness is a precondition for financial opening. This is the optimal sequence question, which has been raised by many, including, most notably, McKinnon (1991). According to McKinnon's hypothesis, liberalizing capital accounts is the last step of economic liberalization and must be implemented only if trade openness is achieved.

Although this hypothesis has been influential, empirical evidence has been mixed. Haggard and Maxfield (1993) shows that trade openness is a precondition for removing capital controls whereas Leblang (1997) does not find any evidence for the influence from trade openness on capital account liberalization. Aizenman and Noy (2004) find that financial openness and trade openness are bidirectional, though financial openness seems to lead to trade openness more than the other way around. Tornell et al. (2004) also show that financial liberalization has typically followed trade liberalization over the last two decades.

Recently, the sequencing issue is getting more attention in the Asian region because of the efforts for regional economic integration. Table 5 reports the correlations between the index for financial openness, KAOPEN, and that for trade openness, TRADEOPEN, whose definition will be explained more carefully below. In this table, the link between financial and trade openness is exceptionally high for Asia than any other groups. The high correlation also appears to be stable throughout the three decades.

I empirically explore the hypothesis of trade openness being a precondition for financial 
opening by employing a simple model that accounts for the determinants of financial openness or restrictions. As stated in equation (3), I model financial openness as the function of government budget surplus, international reserves, trade openness, and per capita GDP. ${ }^{25}$

(3) $\mathrm{KAOPEN}_{t}=\xi_{0}+\xi_{1} \mathrm{KAOPEN}_{t-5}+\xi_{2} \operatorname{TRADEOPEN}_{t-5}+Z_{t-1 \mid t-5} \Xi+v_{t}$,

where $Z_{t-1 \mid t-5}$ is a vector of macroeconomic control variables, namely, government budget surplus, international reserves, and per capita GDP. ${ }^{26}$ I select two variables - the government budget surplus and international reserves - since they are most commonly argued as the determinants of capital controls. ${ }^{27,28}$ The variable for per capita GDP is also included to control for the level of development of the economic system. Since these variables are supposed to control for the general trend of macro variables, they are included as the 5-year average prior to the time period $t$ (as shown as $(t-1 \mid t-5)$ in the regression results table).

As the trade openness variable, I use a new variable TRADEOPEN which is a reciprocal of the weighted average (based on the share of imports and exports in total trade) of duties imposed on both imports and exports. ${ }^{29}$ Because the relationship between trade openness and KAOPEN which essentially measures de jure openness in cross-border financial transactions is of most interest here, TRADEOPEN, an index on de jure trade openness, is more appropriate than opn (the sum of exports and imports divided by GDP), which is used in the previous estimations and measures de facto trade openness.

\footnotetext{
${ }^{25}$ The empirical model also controls for regional differences by regional dummies.

${ }^{26}$ The variable for gross international reserves is a proxy to the balance of payments situation of the countries and is measured by gross international reserves in months of imports. The lower gross reserves in months of imports, the higher prevalence of balance of payments concerns are. The data are extracted from the World Bank's World Development Indicators.

${ }^{27}$ Grilli and Milesi-Ferretti (1995) show that capital controls have strong fiscal implications, i.e., countries with a less developed tax system tend to implement capital controls as the source of government revenue as well as the remedy to capital flows caused by the inflation-driven distortions in the financial markets. Johnston and Tamirisa (1998) find that countries tend to implement capital controls, the more prevalent the balance of payments concerns are. For more discussion of the macroeconomic determinants of capital controls, refer to Leblang (1997).

${ }^{28}$ In addition to the above variables, I included variables that refer to the government engagement in seigniorage, such as the inflation rate or the reserve ratio. However, these measures of seigniorage can cause multicollinearity in regression analysis due to its correlation with the level of government budget surplus, the reverse of which is often the reason for seigniorage. Therefore, I decided not to include seigniorage-related variables in the regression model.

Because the analysis in this subsection also functions as a preliminary analysis for the two stage least squares (2SLS) estimation in the next subsection, I maintain the estimation model as parsimonious as possible.

${ }^{29}$ Import and export duties as a ratio to imports and exports, respectively, are available from the World Bank's WDI. The higher (or close to 100) TRADEOPEN is, the less duties imposed on trade flows in both directions, i.e., the more
} 
I also test whether the reverse causality, i.e., financial openness leads to trade openness, holds. To maintain the parsimony of the model, the places for KAOPEN and TRADEOPEN in equation (3) are switched for the regression analysis. Considering that tariff policy is often motivated by the fiscal conditions of countries, it is reasonable to keep the term for budget balance in the regression equation. However, the variable for international reserves is not retained because it lacks a theoretical motivation.

In order to minimize the possibility of two-way causality, in both types of regressions, I employ a non-overlapping panel data analysis as in previous analyses. While the macro variables are included as the five-year average, both KAOPEN and TRADEOPEN are included as the initial conditions of each five-year panel. In the empirical analysis, we focus on the coefficient $\xi_{2}$ (or the coefficient of the five-year lagged financial openness for the other type of regression) to see if the trade openness can be a precondition for financial opening, or the reversed causality is true.

The first three columns of Table 6 report the results for the regressions on whether trade openness leads to financial openness. While the average budget surplus and GDP per capita enter significantly, but not international reserves, the trade openness variable seems to significantly contribute to the level of financial openness in all sample groups, indicating that the openness in goods transactions is a precondition for financial openness. Interestingly, when the same exercise is repeated for the group of Latin American countries (not reported), the coefficient of the trade openness variable becomes insignificant with a large drop in the $p$-value.

Columns (4) through (6) of Table 6 show the results on whether the reverse causality also holds. In all the samples, the financial openness variable does not enter significantly. Hence, I can safely conclude that the more openness in goods transactions can lead to a more openness in capital account, but the reverse causality does not appear to be present.

\subsection{Endogeneity and the Sequence of Liberalization}

Taking a cue from the results reported above, I implement two stage least squares (2SLS) estimation instrumenting the $K A O P E N_{t-5}$ variable in equation (1) to investigate whether financial opening preceded by trade opening leads to financial development. The instrumental variables are the initial conditions of financial and trade openness five years prior to the variable as well as 
government budget surplus and GDP per capita as the five-year average prior to $t-5$ and regional dummies. ${ }^{30}$

The results of applying 2SLS to a model that controls for the general development level of legal systems and institutions (LEGAL1) are reported in Table 7. For the model with stock market total value (SMTV) of the group of less developed countries, we can see that both the magnitude and the statistical significance of the estimated coefficients for the level KAOPEN, LEGAL1, and interactive terms increase. For the Asian sample, the interactive term remains significant while the level KAOPEN term does not (the $p$-value is $29 \%$ ). For the SMKC models, the level of financial openness becomes significant contributors to equity market development for both the LDC and Asian groups. Given these results, we may conclude that financial opening succeeding trading opening leads to equity market development especially when it takes place in an economy with a reasonably developed legal system. This conclusion is applicable to the Asian sample with a somewhat lesser degree.

\section{Concluding Remarks}

This paper examined the nexus between capital account liberalization and financial development with a focus on the Asian region. A casual examination of summary statistics showed that in recent decades this region has achieved high growth in both equity market development as well as the level of openness toward cross-border financial transactions. Given this observation, I investigated a question which policy makers in the Asian region are contemplating, that is, "what is the 'right way' of implementing liberalization?” Despite its intrinsic interest, there has not been much empirical work aimed at answering this question. This paper addresses that deficiency. Specifically, two issues are examined. First, what kind of institutional settings have made financial liberalization successful in fostering financial, especially equity, market development in Asia as well as other less developed countries? Secondly, this paper investigated whether there is empirical evidence to support the McKinnon hypothesis on the optimal sequence of liberalization, i.e., trade openness should precede financial openness.

\footnotetext{
${ }^{30}$ The international reserves variable is not included because of its insignificance in the previous analysis. The regional dummies are not included as IVs for the Asia and non-Asian LDC subsamples.
} 
On the first point, the empirical results suggest that financial openness does contribute to equity market development - measured as activity of the stock market - but only when a threshold level of general development of legal systems and institutions has been attained, a condition which is more prevalent among Asian countries, especially emerging market Asian countries, than among the entire set of developing countries. ${ }^{31}$ When the specific effects of legal/institutional development are examined, a higher level of bureaucratic quality and law and order, as well as a lower level of corruption, are found to enhance the effect of financial opening in fostering the development of equity markets. For the Asian set of countries, corruption and law and order appear to matter for equity market development while the quality of bureaucracy does not. Interestingly, finance-specific legal institutions do not seem to fulfill the same role, indicating that the general level of legal development matters more than the level of finance-specific legal/institutional development. These results are robust to the presence of outliers in the data and simultaneity as well as to different model specifications, so I conclude that increasing the level of openness in cross-border financial transactions - when a reasonable level of legal and institutional development is achieved - can lead to development in equity markets.

On the McKinnon hypothesis, the opening of goods markets is found to be a precondition for financial opening in less developed sample as well as the Asian subsample. However, the reverse causal link does not hold for any of the sample groups. When the financial openness variable is instrumented with trade openness, the contribution of the general level of legal development still remains significant for the group of less developed countries and with a somewhat lesser degree for the Asian sample. I interpret this finding as evidence that an increase in trade openness is a prolog to financial openness, and thence to financial development.

These findings suggest that the uniquely high level of equity market development in the Asian region can be explained by the policy of financial openness in the presence of a highly developed legal infrastructure as well as trade openness.

\footnotetext{
${ }^{31}$ This finding is consistent with Klein (2005) who argues that the effectiveness of capital account liberalization on economic growth is non-monotonic and depends upon the level of institutional quality. Klein, however, demonstrates that the relationship between institutional quality and the responsiveness of economic growth to capital account liberalization is inverted-U shaped; countries with better (but not the best) institutions exhibit a statistically significant effect of capital account openness on economic growth.
} 


\section{Appendix 1: Country list (108 countries)}

\section{Asia (15)}

$\begin{array}{rrcl}1 & 513 & \text { BGD } & \text { Bangladesh }^{\mathrm{e}} \\ 2 & 924 & \text { CHN } & \text { China }^{\text {e }} \\ 3 & 819 & \text { FJI } & \text { Fiji } \\ 4 & 532 & \text { HKG } & \text { Hong Kong }^{\mathrm{e}} \\ 5 & 534 & \text { IND } & \text { India }^{\text {e }} \\ 6 & 536 & \text { IDN } & \text { Indonesia }^{\mathrm{e}} \\ 7 & 542 & \text { KOR } & \text { Korea }^{\mathrm{e}} \\ 8 & 548 & \text { MYS } & \text { Malaysia }^{\mathrm{e}} \\ 9 & 558 & \text { NPL } & \text { Nepal }^{\mathrm{e}} \\ 10 & 564 & \text { PAK } & \text { Pakistan }^{\mathrm{e}} \\ 11 & 853 & \text { PNG } & \text { Papua New Guinea }_{12} \\ 12 & 566 & \text { PHL } & \text { Philippines }^{\mathrm{e}} \\ 13 & 576 & \text { SGP } & \text { Singapore }^{\mathrm{e}} \\ 14 & 524 & \text { LKA } & \text { Sri Lanka }^{\mathrm{e}} \\ 15 & 578 & \text { THA } & \text { Thailand }^{\mathrm{e}}\end{array}$

\section{Other countries (93)}

$\begin{array}{rlll}1 & 612 & \text { DZA } & \text { Algeria } \\ 2 & 213 & \text { ARG } & \text { Argentina }^{\text {e }} \\ 3 & 193 & \text { AUS } & \text { Australia }^{\text {i }} \\ 4 & 122 & \text { AUT } & \text { Austria }^{\text {i }} \\ 5 & 313 & \text { BHS } & \text { Bahamas, The } \\ 6 & 419 & \text { BHR } & \text { Bahrain, Kingdom of }^{\text {e }} \\ 7 & 316 & \text { BRB } & \text { Barbados }^{\text {i }} \\ 8 & 124 & \text { BEL } & \text { Belgium } \\ 9 & 339 & \text { BLZ } & \text { Belize } \\ 10 & 638 & \text { BEN } & \text { Benin } \\ 11 & 218 & \text { BOL } & \text { Bolivia } \\ 12 & 616 & \text { BWA } & \text { Botswana } \\ 13 & 223 & \text { BRA } & \text { Brazil } \\ 14 & 748 & \text { BFA } & \text { Burkina Faso } \\ 15 & 618 & \text { BDI } & \text { Burundi } \\ 16 & 622 & \text { CMR } & \text { Cameroon }\end{array}$

\begin{tabular}{|c|c|c|c|}
\hline 17 & 156 & CAN & Canada $^{\mathrm{i}}$ \\
\hline 18 & 626 & CAF & Central African Rep. \\
\hline 19 & 628 & TCD & Chad \\
\hline 20 & 228 & CHL & Chile $^{\mathrm{e}}$ \\
\hline 21 & 233 & COL & Colombia $^{\mathrm{e}}$ \\
\hline 22 & 634 & COG & Congo, Republic of \\
\hline 23 & 238 & CRI & Costa Rica \\
\hline 24 & 662 & CIV & Cote d'Ivoire $^{\mathrm{e}}$ \\
\hline ל2 & 423 & CYP & Cyprus \\
\hline 26 & 128 & DNK & Denmark $^{\mathrm{i}}$ \\
\hline 27 & 243 & DOM & Dominican Republic \\
\hline 28 & 248 & ECU & Ecuador $^{\mathrm{e}}$ \\
\hline 29 & 469 & EGY & Egypt $^{e}$ \\
\hline 30 & 253 & SLV & El Salvador \\
\hline 31 & 172 & FIN & Finland $^{\mathrm{i}}$ \\
\hline 32 & 132 & FRA & France $^{\mathrm{i}}$ \\
\hline 33 & 646 & GAB & Gabon \\
\hline 34 & 648 & GMB & Gambia, The \\
\hline 35 & 134 & DEU & Germany $^{\mathrm{i}}$ \\
\hline 36 & 652 & GHA & Ghana ${ }^{e}$ \\
\hline 37 & 174 & GRC & Greece $^{\mathrm{i}, \mathrm{e}}$ \\
\hline 38 & 258 & GTM & Guatemala \\
\hline 39 & 263 & HTI & Haiti \\
\hline 40 & 268 & HND & Honduras \\
\hline 41 & 176 & ISL & Iceland ${ }^{\mathrm{i}}$ \\
\hline 42 & 429 & IRN & Iran, Islamic Rep. of \\
\hline 43 & 178 & IRL & Ireland ${ }^{\mathrm{i}}$ \\
\hline 44 & 436 & ISR & Israel $^{\mathrm{e}}$ \\
\hline 45 & 136 & ITA & Italy $^{\mathrm{i}}$ \\
\hline 46 & 343 & JAM & Jamaica $^{e}$ \\
\hline 47 & 158 & JPN & Japan $^{\text {i }}$ \\
\hline 48 & 439 & JOR & Jordan $^{\mathrm{e}}$ \\
\hline 49 & 664 & KEN & Kenya ${ }^{\text {e }}$ \\
\hline 50 & 443 & KWT & Kuwait \\
\hline 51 & 666 & LSO & Lesotho \\
\hline 52 & 674 & MDG & Madagascar \\
\hline 53 & 676 & MWI & Malawi \\
\hline 54 & 678 & MLI & Mali \\
\hline 55 & 181 & MLT & Malta \\
\hline 56 & 682 & MRT & Mauritania \\
\hline
\end{tabular}

MUS Mauritius

MEX Mexico $^{\mathrm{e}}$

MAR Morocco

New Zealand

NGA Nigeria

NOR Norway ${ }^{i}$

OMN Oman ${ }^{\mathrm{e}}$

PAN Panama

PRT Portugal ${ }^{\mathrm{i},}$

Saudi Arabia

SEN Senegal

SYC Seychelles

SLE Sierra Leone

ZAF South Africa ${ }^{e}$

ESP Spain ${ }^{1}$

SWZ Swaziland

SWE Sweden

CHE Switzerland

SYR Syrian Arab Republic

TZA Tanzania

TGO Togo

TTO Trinidad and Tobago ${ }^{\mathrm{e}}$

TUN Tunisia ${ }^{e}$

TUR Turkey

UGA Uganda

GBR United Kingdom

USA United States

URY Uruguay

VEN Venezuela, Rep. Bol.

ZMB Zambia

ZWE Zimbabwe ${ }^{\mathrm{e}}$

i - industrialized countries (IDC), 22 countries e - emerging market countries (EMG), 31 countries (Standard \& Poor (2000)) 


\section{Appendix 2: The “Chinn-Ito” Index}

KAOPEN is an index to measure a country's degree of capital account openness. The dataset encompasses the time period of 1970-2000 for 108 countries. For a complete list of the countries, see the attached country list.

\section{Construction of KAOPEN}

KAOPEN is based on the four binary dummy variables reported in the IMF's Annual Report on Exchange Arrangements and Exchange Restrictions (AREAER). These variables are to provide information on the extent and nature of the restrictions on external accounts for a wide cross-section of countries. These variables are:

- $\quad k_{1}$ : variable indicating the presence of multiple exchange rates;

- $\quad k_{2}$ : variable indicating restrictions on current account transactions;

- $\quad k_{3}$ : variable indicating restrictions on capital account transactions; and

- $\quad k_{4}$ : variable indicating the requirement of the surrender of export proceeds.

In order to focus on the effect of financial openness - rather than controls - we reverse the values of these binary variables, such that the variables are equal to one when the capital account restrictions are non-existent. Moreover, for controls on capital transitions $\left(k_{3}\right)$, we use the share of a five-year window (encompassing year $t$ and the preceding four years) that capital controls were not in effect (SHAREk $\left.k_{3}\right)$.

$$
\operatorname{SHAREk}_{3, t}=\left(\frac{k_{3, t}+k_{3, t-1}+k_{3, t-2}+k_{3, t-3}+k_{3, t-4}}{5}\right)
$$

Then we construct an index for capital "openness" $\left(K A O P E N_{t}\right)$, which is the first standardized principal component of $k_{1 t}, k_{2 t} S H A R E k_{3}, k_{4 t}{ }^{32}$ This index takes on higher values the more open the country is to cross-border capital transactions. By construction, the series has a mean of zero. The first eigenvector for KAOPEN was found to be $\left(S H A R E k_{3}, k_{1}, k_{2}, k_{4}\right)^{\prime}=(0.573,0.273,0.521$, 0.571 )', indicating that the variability of KAOPEN is not merely driven by the $S H A R E k_{3}$ series.

We incorporate the $k_{1, t}, k_{2, t}$, and $k_{4, t}$ variables in our KAOPEN variable instead of focusing on $k_{3}$ which refers to restrictions on capital account transactions. We believe the incorporation of $k_{1, t}$, $k_{2, t}$, and $k_{4, t}$ in this index allows us to more accurately capture the intensity of the capital controls. This point can be made more concrete by considering a country with an open capital account. It may still restrict the flow of capital by limiting transactions on the current account restrictions or other systems such as multiple exchange rates and requirements to surrender export proceeds. Alternatively, countries that already have closed capital accounts might try to increase the stringency of those controls by imposing $k_{1}, k_{2}$, and $k_{4}$ types of restrictions so that the private sector cannot circumvent the capital account restrictions.

\footnotetext{
${ }^{32}$ For the extension of the four binary variables after the disaggregation of the AREAER classification in 1996, we followed Mody and Murshid (2005).
} 
By the nature of its construction, one may argue that the KAOPEN index measures the extensity of capital controls because it may not directly refer to the stringency of restrictions on cross-border transactions, but to the existence of different types of restrictions. However, measuring the extensity of capital controls may be a good proxy to the measure of intensity of capital controls. One might think of the Quinn (1997) index or the Miniane (2004) index as the measures of the intensity of capital controls. The correlation between the Chinn-Ito index and the Quinn or Miniane index is found to be $83.9 \%$ and $80.2 \%$, respectively, suggesting that KAOPEN is proxying the intensity of capital controls.

Clearly, the measurement of the extent of capital account controls is a difficult enterprise. Many researchers have tried to capture the complexity of real-world capital controls, with varying degrees of success, and varying degrees of coverage. For reviews and comparisons of various measures on capital controls, refer to Edwards (2001), Edison et al. (2002) and Eichengreen (2002).

Acknowledgements: This paper was presented at "Regional Economic Integration in Asia" (Lowe Institute of Political Economy at Claremont McKenna College and the Freeman Program in Asian Political Economy), and "Remaking Economic Strengths In East Asia” (UC Berkeley). At both conferences, this paper was previously titled as "What Matters for Financial Development in Asia?” I thank Joshua Aizenman, Menzie Chinn, Barry Eichengreen, Mark Spiegel, Tom Willett, and the conference participants for helpful comments, and. Ashok Mody and Dennis Quinn for providing data. 


\section{References}

Aizenman, J. (2002). Financial opening: evidence and policy options. National Bureau of Economic Research Working Paper No. 8900.

Aizenman, J. \& Noy, I. (2004). On the two way feedback between financial and trade openness. National Bureau of Economic Research Working Paper No. 10496.

Arteta, C., Eichengreen, B. \& Wyplosz, C. (2001). When does capital account liberalization help more than it hurts? National Bureau of Economic Research Working Paper No. 8414.

Beck, T., Demirgüc-Kunt, A., \& Levine, R. (2000). A new database on financial development and structure. Policy Research Paper No. 2147. Washington, D.C.: World Bank.

Beck, T. \& Levine, R. (2002). Industry growth and capital allocation: does having a market- or bank-based system matter? Journal of Financial Economics 64, 147 - 180.

Beim, D., \& Calomiris, C. W. (2001). Emerging Financial Markets. New York: McGraw Hill. Bekaert, G., Harvey, C. \& Lundblad, C. (2001). Does financial liberalization spur growth? National Bureau of Economic Research Working Paper No. 8245.

Bekaert, G., Harvey, C. \& Lundblad, C. (2000). Emerging equity market and economic development. National Bureau of Economic Research Working Paper No. 7763.

Brown, S. J. \& Goetzmann, W. N. (2001). Hedge funds with style. Yale ICF Working Paper No. 00-29.

Brown, S. J., Goetzmann, W. N. \& Park, J. M. (1998). Hedge funds and the Asian currency crisis of 1997. Yale School of Management Working Paper No. F-58.

Caprio, G., Laeven, L., \& Levine, R. (2004). Governance and bank valuation. University of Minnesota, unpublished manuscript.

Cavoli, T., Rajan, R. \& Siregar, R. (2003). A survey of financial integration in East Asia: trends, 
issues and implications.” Report prepared for the Asian Development Bank.

Cheung, Y. W., Chinn, M. D., \& Fujii, E. (2003). Chinese economies in global context: the integration process and its determinants. Journal of the Japanese and International Economies, forthcoming.

Chinn, M.D., Dooley, M.P., \& Shrestha, S. (1999). Latin America and East Asia in the context of an insurance model of currency crises. Journal of International Money and Finance 18, 659-681. Chinn, M. D. \& Ito, H. (2002). Capital account liberalization, institutions and financial development: cross country evidence. National Bureau of Economic Research Working Paper No. 8967.

Claessens, S., Djankv, S., Fan, J., Lang, L. (2002). Expropriation of minority shareholders in East Asia. Journal of Finance 57.

Claessens, S., Demirgüc-Kunt, A., \& Huizinga, H. (2001). How does foreign entry affect domestic banking markets? Journal of Banking and Finance. 25, pp. 891 - 911.

Corsetti, G., Pesenti, P., \& Roubini, N. (1998). Paper tigers? A preliminary assessment of the Asian crisis. National Bureau of Economic Research Working Paper Series No. 6783.

De Gregorio, J. (1998). Financial integration, financial development and economic growth. Chile: Department of Industrial Engineering, Universidad de Chile, unpublished manuscript. Edison, H. J., Klein, M. W., Ricci, L. \& Sløk, T. (2002). Capital account liberalization and economic performance: a review of the literature. mimeo. Washington, D.C.: IMF.

Edison, H. J. \& Warnock F. E. (2001). A simple measure of the intensity of capital controls. International Finance Discussion Paper No. 708. Washington, D.C.: Board of Governors of the Federal Reserve System. 
Edwards, S. (2001). Capital mobility and economic performance: are emerging economies different? National Bureau of Economic Research Working Paper No. 8076.

Edwards, S. (1999). How effective are capital controls? Journal of Economic Perspectives 13, 65-84.

Eichengreen, B. (2004). Real and pseudo preconditions an Asian monetary union. paper presented at the Asian Development Bank High-Level Conference on Asia’s Economic Cooperation and integration, Manila, July 1-2.

Eichengreen, B. (2002). Capital account liberalization: what do the cross-country studies tell us? World Bank Economic Review 15, 3, 341 - 365.

Fung, W. \& Hsieh, D. A. (2001). The risk in hedge fund strategies: theory and evidence from trend followers. Review of Financial Studies, 14, 313-341.

Grilli, V. \& Milesi-Ferretti, G. M. (1995). Economic effects and structural determinants of capital controls. IMF Staff Papers 42(3): 517 - 51.

Haggard, S. \& Maxfield, S. (1993). The political economy of capital account liberalization. In H. Reisen \& B. Fischer (Eds.), Financial Opening: Policy Issues and Experiences in Developing Countries. Paris: OECD.

Henry, P. B. (2000). Stock market liberalization, economic reform and emerging market equity prices. Journal of Finance 55(2), 529-564.

International Monetary Fund (2001). World Economic Outlook. Washington, D.C.: IMF. Ito, H. (2004). Is financial openness a bad thing? An analysis on the correlation between financial liberalization and the output performance of crisis-hit economies. Santa Cruz Center for International Economics Working Paper Series No. 04-23. 
Johnson, S., McMillan, J., \& Woodruff, C. (2002) Property rights and finance. American Economic Review 92, 1335 - 56.

Johnston, R. B. \& Tamirisa, N. T. (1998). Why do countries use capital controls? IMF Working Paper WP/98/181. Washington, D.C.: IMF.

Kaminsky, G.L. (2003). Varieties of currency crises. National Bureau of Economic Research Working Paper Series No. 10193.

Kaminsky, G.L., Lizondo, J.S., \& Reinhart, C.M. (1998). Leading indicators of currency crises. IMF Staff Papers 45, 1-48.

Kaminsky, G., \& Schmukler, S. (2002). Short-run pain, long-run gain: the effects of financial liberalization. World Bank Working Paper No. 2912.

Kaminsky, G., \& Schmukler, S. (2001a). Short- or long-run integration: do capital controls matter. Brookings Trade Forum 2000. Washington, DC: Brookings Institution, 125-178.

Kaminsky, G., \& Schmukler, S. (2001b). On booms and crashes: financial liberalization and stock market cycles. Washington, D.C.: World Bank, unpublished manuscript.

Kim, W. \& Wei, S. J. (2002). Offshore investment funds: monsters in emerging markets? Journal of Development Economics, 2002, Vol. 848.

Klein, M. (2005). Capital account liberalization, institutional quality and economic growth: theory and evidence. National Bureau of Econoimic Research Working Paper No. 11112.

Klein, M. \& Olivei, G. (2001). Capital account liberalization, financial depth and economic growth. Medford, MA: Tufts, Unpublished manuscript.

Kletzer, K. \& Mody, A. (2000). Will self-protection policies safeguard emerging markets from crises? In C. Adams, R. E. Litan, \& M. Pomerleano (Eds.) Managing Financial and Corporate Distress : Lessons from Asia. Washington, D.C.: Brookings Institution. 
La Porta, R., Lopez-de-Silanes, F., Shleifer, A., \& Vishny, R.W. (1998). Law and finance. Journal of Political Economy 106, 113 - 1155.

La Porta, R., Lopez-de-Silanes, F., Shleifer, A., \& Vishny, R.W. (1997). Legal determination of external finance. Journal of Finance 52, 1131 - 1150.

Leahy, M., Schich, S., Wehinger, G., Pelgrin, F. \& Thorgeirsson, T. (2001). Contributions of financial systems to growth in OECD countries. OECD Economic Department Working Papers No. 280.

Leblang, D. A. (1997). Domestic and systematic determinants of capital controls in the developed and developing world. International Studies Quarterly, 41, 435 - 454.

Levine, R. (2002). Bank-based or market-based financial systems: which is better? Journal of Financial Intermediation 11, 398 - 428.

Levine, R. (1998). Stock markets, banks, and economic growth. American Economic Review 88, $537-58$.

McKinnon, R. I. (1991). The Order of Economic Liberalization: Financial Control in the Transition to a Market Economy. Baltimore: Johns Hopkins University Press.

McKinnon, R. I. (1973). Money and Capital in Economic Development. Washington, DC: Brookings Institution.

Miniane, J. (2004). A new set of measures on capital account restrictions. IMF Staff Papers 51(2). Neely, C. (1999). An introduction to capital controls. Review. Federal Bank of St. Louis, November/December.

Montiel, P. (1995). Capital mobility in developing countries: Some measurement issues and empirical estimates. World Bank Economic Review 8: 311-350. 
Pomfret, R. (2005). Sequencing trade and monetary integration. paper presented at the Workshop on "Regional Economic Integration in Asia” held by the Lowe Institute of Political Economy, Claremont McKenna College, February 24.

Quinn, D. (1997). The correlates of change in international financial regulation. American Political Science Review 91(3): 531-551.

Quinn, D., Toyoda, A. M. \& Inclan, C. (2002). Does capital account liberalization lead to economic growth?: An empirical investigation. Washington, D.C.: Georgetown University. Unpublished manuscript.

Rajan, R. G. \& Zingales, L. (2003). The great reversals: the politics of financial development in the $20^{\text {th }}$ century. Journal of Financial Economics 69.

Sachs, J.D., Tornell, A., \& Velasco, A. (1996). Financial crises in emerging markets: the lessons from 1995. National Bureau of Economic Research Working Paper Series No. 5576.

Schmukler, S. (2003). Financial globalization: gains and pain for developing countries.

Washington, D.C.: World Bank, Unpublished manuscript.

Shaw, E. (1973). Financial Deepening in Economic Development. New York: Oxford University Press.

Stiglitz, J. (2000). Capital market liberalization, economic growth, and instability. World Development, 28:6, 1075 - 1086.

Stultz, R. (1999). Globalization, corporate finance and the cost of capital. Journal of Applied Corporate Finance, v12(3), 8-25.

Spiegel, M. (2001). Financial development and growth: are the APEC nations unique? Pacific Basin Working Papers PB01-04. San Francisco: Federal Reserve Bank of San Francisco. 
Takagi, S. \& Hirose, K. (2004). A multivariate approach to grouping financially integrated economies. In Kawai, M. \& de Brouwer, G. (Eds.), Exchange Rate Regimes in East Asia, New York: Routledge.

Tornell, A., Westermann, F., \& Martinez, L. (2004). The positive link between financial liberalization, growth, and crises. National Bureau of Economic Research Working Paper Series No. 10293.

Wei, S. J. (2000). Local corruption and global capital flows. Brookings Papers on Economic Activity, No.2: 303-354. 
Table 1: Growth rates of PCGDP, SMKC, SMTV, and SMTO $1970-2000$ and decades

\begin{tabular}{|c|c|c|c|c|}
\hline & \multicolumn{4}{|c|}{ Growth rates of } \\
\hline & $\begin{array}{c}\text { Private Credit } \\
\text { Creation } \\
\text { (PCGDP) }\end{array}$ & $\begin{array}{l}\text { Stock Market } \\
\text { Capitalization } \\
\text { (SMKC) }\end{array}$ & $\begin{array}{c}\text { Stock Market } \\
\text { Total Value } \\
\text { (SMTV) }\end{array}$ & $\begin{array}{c}\text { Stock Market } \\
\text { Turnover } \\
\text { (SMTO) }\end{array}$ \\
\hline \multicolumn{5}{|c|}{$1970-2000$} \\
\hline Full & $0.87 \%$ & $1.93 \%$ & $1.87 \%$ & $2.47 \%$ \\
\hline IDC & $1.74 \%$ & $2.96 \%$ & $3.67 \%$ & $3.45 \%$ \\
\hline LDC & $0.61 \%$ & $1.32 \%$ & $0.84 \%$ & $1.87 \%$ \\
\hline EMG & $0.91 \%$ & $1.49 \%$ & $1.09 \%$ & $2.49 \%$ \\
\hline Asia & $1.17 \%$ & $1.67 \%$ & $1.86 \%$ & $3.89 \%$ \\
\hline Non-Asian LDC & $0.48 \%$ & $1.15 \%$ & $0.40 \%$ & $0.94 \%$ \\
\hline Latin America & $0.60 \%$ & $1.16 \%$ & $0.08 \%$ & $-0.03 \%$ \\
\hline \multicolumn{5}{|c|}{$1970-1979$} \\
\hline Full & $0.62 \%$ & $0.47 \%$ & $0.18 \%$ & $0.35 \%$ \\
\hline IDC & $0.77 \%$ & $-0.22 \%$ & $0.25 \%$ & $-0.35 \%$ \\
\hline LDC & $0.57 \%$ & $1.70 \%$ & $0.11 \%$ & $1.85 \%$ \\
\hline EMG & $0.70 \%$ & $1.29 \%$ & $0.09 \%$ & $1.55 \%$ \\
\hline Asia & $0.78 \%$ & $1.14 \%$ & $-0.02 \%$ & $0.40 \%$ \\
\hline Non-Asian LDC & $0.52 \%$ & $2.52 \%$ & $0.21 \%$ & $4.10 \%$ \\
\hline Latin America & $0.48 \%$ & $0.64 \%$ & $0.15 \%$ & $7.17 \%$ \\
\hline \multicolumn{5}{|c|}{$1980-1989$} \\
\hline Full & $0.68 \%$ & $1.52 \%$ & $1.33 \%$ & $1.98 \%$ \\
\hline IDC & $1.99 \%$ & $2.89 \%$ & $2.25 \%$ & $3.61 \%$ \\
\hline LDC & $0.30 \%$ & $0.53 \%$ & $0.70 \%$ & $0.78 \%$ \\
\hline EMG & $0.49 \%$ & $0.70 \%$ & $0.82 \%$ & $1.16 \%$ \\
\hline Asia & $1.06 \%$ & $0.61 \%$ & $1.79 \%$ & $1.98 \%$ \\
\hline Non-Asian LDC & $0.14 \%$ & $0.48 \%$ & $0.14 \%$ & $0.08 \%$ \\
\hline Latin America & $-0.01 \%$ & $0.21 \%$ & $0.07 \%$ & $0.05 \%$ \\
\hline \multicolumn{5}{|c|}{$1990-2000$} \\
\hline Full & $1.08 \%$ & $3.33 \%$ & $3.72 \%$ & $3.81 \%$ \\
\hline IDC & $1.95 \%$ & $5.59 \%$ & $7.51 \%$ & $4.40 \%$ \\
\hline LDC & $0.85 \%$ & $2.27 \%$ & $1.99 \%$ & $3.53 \%$ \\
\hline EMG & $1.35 \%$ & $2.66 \%$ & $3.00 \%$ & $5.14 \%$ \\
\hline Asia & $1.46 \%$ & $3.50 \%$ & $5.07 \%$ & $9.84 \%$ \\
\hline Non-Asian LDC & $0.71 \%$ & $1.78 \%$ & $0.84 \%$ & $1.05 \%$ \\
\hline Latin America & $1.30 \%$ & $1.80 \%$ & $0.16 \%$ & $-0.05 \%$ \\
\hline \multicolumn{5}{|c|}{$1995-2000$} \\
\hline Full & $1.58 \%$ & $3.03 \%$ & $4.81 \%$ & $5.08 \%$ \\
\hline IDC & $3.10 \%$ & $9.50 \%$ & $12.06 \%$ & $6.52 \%$ \\
\hline LDC & $1.19 \%$ & $0.25 \%$ & $1.66 \%$ & $4.45 \%$ \\
\hline EMG & $1.78 \%$ & $-0.39 \%$ & $2.83 \%$ & 7.30\% \\
\hline Asia & $1.81 \%$ & $-1.78 \%$ & $3.95 \%$ & $15.04 \%$ \\
\hline Non-Asian LDC & $1.05 \%$ & $0.99 \%$ & $0.85 \%$ & $0.62 \%$ \\
\hline Latin America & $1.59 \%$ & $0.75 \%$ & $-0.33 \%$ & $-1.06 \%$ \\
\hline
\end{tabular}

Notes: For the data description, refer to the text. The original data are extracted from the updated version of the Beck, Demirgüc-Kunt, and Levine (2000) dataset. 
Tale 2: Averages of KAOPEN and change in KAOPEN, $1970-2000$ and decades

\begin{tabular}{c|c|c|c|c|c}
\hline & \multicolumn{5}{|c}{ Averages of KAOPEN } \\
\cline { 2 - 6 } & $1970-2000$ & $1970 \mathrm{~s}$ & $1980 \mathrm{~s}$ & $1990 \mathrm{~s}$ & $1995-2000$ \\
\hline \hline Full & 0.000 & -0.278 & -0.296 & 0.485 & 0.679 \\
IDC & 1.125 & 0.257 & 0.804 & 2.152 & 2.407 \\
LDC & -0.288 & -0.424 & -0.570 & 0.069 & 0.241 \\
EMG & -0.255 & -0.547 & -0.571 & 0.274 & 0.555 \\
Asia & -0.004 & -0.375 & -0.010 & 0.292 & 0.227 \\
Non-Asia LDC & -0.348 & -0.434 & -0.688 & 0.021 & 0.244 \\
Latin America & -0.085 & 0.075 & -0.779 & 0.402 & 0.857 \\
\hline
\end{tabular}

Notes: KAOPEN is an index for the openness in capital account transactions and is the first standardized principal component of SHAREk3, k1, $k 2$, and $k 4$. $k_{1}$ indicates the presence of multiple exchange rates; $k_{2}$ indicates restrictions on current account transactions; $k_{3}$ indicates restrictions on capital account transactions; and $k_{4}$ indicates the requirement of the surrender of export proceeds. In order to focus on the effect of financial openness - rather than controls - we reverse the values of these binary variables, such that the variables are equal to one when the capital account restrictions are non-existent. The first eigenvector for KAOPEN was found to be $\left(\text { SHAREk }_{3}, k_{1}, k_{2}, k_{4}\right)^{\prime}=(0.573,0.273,0.521,0.571)^{\prime}$, indicating that the variability of KAOPEN is not merely driven by the SHAREk $k_{3}$ series. The average of KAOPEN across countries over the full time period is zero by construction. See Appendix 2 for more details. 
Table 3-1: Financial Development, Financial Openness, and Legal/Institutional Development (LEGAL1: General Legal/Institutional Development)

LDC, ASIA, and non-Asian LDC: Five year panels, 1980-2000

\begin{tabular}{|c|c|c|c|c|c|c|c|c|c|c|}
\hline & \multirow[b]{2}{*}{$\begin{array}{c}\text { Pred. } \\
\text { sign }\end{array}$} & \multicolumn{3}{|c|}{ Private Credit } & \multicolumn{3}{|c|}{ Stock Market Capitalization } & \multicolumn{3}{|c|}{ Stock Market Total Value } \\
\hline & & $\begin{array}{c}\text { LDC } \\
\text { [1] }\end{array}$ & $\begin{array}{c}\text { Asia } \\
\text { [2] }\end{array}$ & $\begin{array}{c}\text { Non-Asia } \\
{[3]}\end{array}$ & $\begin{array}{c}\text { LDC } \\
{[4]}\end{array}$ & $\begin{array}{c}\text { Asia } \\
{[5]}\end{array}$ & $\begin{array}{c}\text { Non-Asia } \\
\text { [6] }\end{array}$ & $\begin{array}{c}\text { LDC } \\
\text { [7] }\end{array}$ & $\begin{array}{c}\text { Asia } \\
{[8]}\end{array}$ & $\begin{array}{c}\text { Non-Asia } \\
\text { [9] }\end{array}$ \\
\hline \multicolumn{11}{|c|}{ Legal/Inst. Variable: LEGAL1 } \\
\hline Financial Openness [t-5] & $(+)$ & $\begin{array}{c}0.0447 \\
{[0.1296]}\end{array}$ & $\begin{array}{c}-0.1419 \\
{[0.3090]}\end{array}$ & $\begin{array}{l}-0.0437 \\
{[0.1474]}\end{array}$ & $\begin{array}{c}0.4986 \\
{[0.7752]}\end{array}$ & $\begin{array}{c}3.0844 \\
{[2.8382]}\end{array}$ & $\begin{array}{c}-0.9067 \\
{[0.5497]^{*}}\end{array}$ & $\begin{array}{c}0.703 \\
{[0.4230]^{*}}\end{array}$ & $\begin{array}{c}0.7472 \\
{[1.3888]}\end{array}$ & $\begin{array}{c}0.5294 \\
{[0.3357]^{12 \%}}\end{array}$ \\
\hline LEVEL: LEGAL1 & $(+)$ & $\begin{array}{c}0.1112 \\
{[0.1409]}\end{array}$ & $\begin{array}{c}0.7114 \\
{[0.5253]}\end{array}$ & $\begin{array}{l}-0.0647 \\
{[0.1521]}\end{array}$ & $\begin{array}{c}1.2558 \\
{[0.8066]^{12 \%}}\end{array}$ & $\begin{array}{c}1.8835 \\
{[1.5713]}\end{array}$ & $\begin{array}{c}0.8404 \\
{[0.9218]}\end{array}$ & $\begin{array}{c}0.9125 \\
{[0.5343]^{*}}\end{array}$ & $\begin{array}{c}1.2868 \\
{[1.4159]}\end{array}$ & $\begin{array}{c}0.6971 \\
{[0.4838]}\end{array}$ \\
\hline $\begin{array}{l}\text { INTERACTION: } \\
\text { LEGAL1x Fin. Open. [t-5] }\end{array}$ & $(+)$ & $\begin{array}{c}-0.089 \\
{[0.0952]}\end{array}$ & $\begin{array}{c}-0.1283 \\
{[0.2773]}\end{array}$ & $\begin{array}{l}-0.1317 \\
{[0.1117]}\end{array}$ & $\begin{array}{c}0.3698 \\
{[0.4335]}\end{array}$ & $\begin{array}{c}1.6174 \\
{[1.3431]}\end{array}$ & $\begin{array}{c}-0.443 \\
{[0.6056]}\end{array}$ & $\begin{array}{c}1.0252 \\
{[0.3454]^{* * *}}\end{array}$ & $\begin{array}{c}1.5588 \\
{[0.8315]^{*}}\end{array}$ & $\begin{array}{c}0.7238 \\
{[0.4355]^{*}}\end{array}$ \\
\hline Financial Deepening [t-5] & $(-)$ & $\begin{array}{c}0.0001 \\
{[0.0119]}\end{array}$ & $\begin{array}{c}-0.0149 \\
{[0.0242]}\end{array}$ & $\begin{array}{c}-0.0048 \\
{[0.0136]}\end{array}$ & $\begin{array}{l}-0.0493 \\
{[0.0380]}\end{array}$ & $\begin{array}{l}-0.0500 \\
{[0.0719]}\end{array}$ & $\begin{array}{c}-0.0491 \\
{[0.0278]^{*}}\end{array}$ & $\begin{array}{c}0.0795 \\
{[0.1187]}\end{array}$ & $\begin{array}{l}-0.1548 \\
{[0.1197]}\end{array}$ & $\begin{array}{c}0.1191 \\
{[0.1585]}\end{array}$ \\
\hline Per Capita Income [t-5] & $(+)$ & $\begin{array}{c}0.0031 \\
{[0.0015]^{* *}}\end{array}$ & $\begin{array}{c}0.0089 \\
{[0.0098]}\end{array}$ & $\begin{array}{c}0.0042 \\
{[0.0014]^{* * *}}\end{array}$ & $\begin{array}{c}0.0187 \\
{[0.0126]}\end{array}$ & $\begin{array}{c}0.0038 \\
{[0.0348]}\end{array}$ & $\begin{array}{c}0.0263 \\
{[0.0157]^{*}}\end{array}$ & $\begin{array}{c}0.0128 \\
{[0.0123]}\end{array}$ & $\begin{array}{c}0.0790 \\
{[0.0516]}\end{array}$ & $\begin{array}{c}0.0091 \\
{[0.0122]}\end{array}$ \\
\hline Inflation [t-5] & $(-)$ & $\begin{array}{l}-0.0047 \\
{[0.0074]}\end{array}$ & $\begin{array}{l}-0.0194 \\
{[0.0452]}\end{array}$ & $\begin{array}{c}-0.0013 \\
{[0.0075]}\end{array}$ & $\begin{array}{c}-0.0497 \\
{[0.0303]^{*}}\end{array}$ & $\begin{array}{c}0.2264 \\
{[0.2805]}\end{array}$ & $\begin{array}{c}-0.0496 \\
{[0.0288]^{*}}\end{array}$ & $\begin{array}{l}-0.0221 \\
{[0.0317]}\end{array}$ & $\begin{array}{l}-0.0290 \\
{[0.2145]}\end{array}$ & $\begin{array}{c}0.0079 \\
{[0.0182]}\end{array}$ \\
\hline Trade Openness [t-5] & $(+)$ & $\begin{array}{c}0.0033 \\
{[0.0035]}\end{array}$ & $\begin{array}{c}-0.0038 \\
{[0.0065]}\end{array}$ & $\begin{array}{c}0.0068 \\
{[0.0046]}\end{array}$ & $\begin{array}{c}0.0137 \\
{[0.0142]}\end{array}$ & $\begin{array}{l}-0.0176 \\
{[0.0417]}\end{array}$ & $\begin{array}{c}0.0183 \\
{[0.0176]}\end{array}$ & $\begin{array}{c}-0.0266 \\
{[0.0158]^{*}}\end{array}$ & $\begin{array}{l}-0.0526 \\
{[0.0335]}\end{array}$ & $\begin{array}{l}-0.0028 \\
{[0.0127]}\end{array}$ \\
\hline $\mathrm{N}$ & & 289 & 57 & 232 & 101 & 37 & 64 & 115 & 40 & 75 \\
\hline Adj. R-sq. & & 0.09 & 0.00 & 0.10 & 0.2 & 0.16 & 0.15 & 0.16 & 0.23 & 0.11 \\
\hline
\end{tabular}

Notes: Point estimates from OLS, heteroskedasticity robust standard errors in parentheses. Dependent variable is the average annual growth rate over a five year period. Financial openness is measured by the Chinn-Ito index (KAOPEN). Regressions include fixed time effects (estimates not reported). Observations of inflation rates in excess of $100 \%$ are dropped from the sample. $(*)[* *]\{* * *\}$ indicates marginal significance at the (10\%)[5\%]\{1\%\} level. 
Table 3-2: Financial Development, Financial Openness, and Legal/Institutional Development (Components of LEGAL1: Corruption, Law and Order, and Bureaucracy Quality)

LDC, ASIA, and non-Asian LDC: Five year panels, 1980-2000

\begin{tabular}{|c|c|c|c|c|c|c|c|c|c|c|}
\hline & \multirow[b]{2}{*}{$\begin{array}{l}\text { Pred } \\
\text { sign }\end{array}$} & \multicolumn{3}{|c|}{ Private Credit } & \multicolumn{3}{|c|}{ Stock Market Capitalization } & \multicolumn{3}{|c|}{ Stock Market Total Value } \\
\hline & & $\begin{array}{l}\text { LDC } \\
{[1]}\end{array}$ & $\begin{array}{c}\text { Asia } \\
\text { [2] }\end{array}$ & $\begin{array}{c}\text { Non-Asia } \\
\text { [3] }\end{array}$ & $\begin{array}{l}\text { LDC } \\
{[4]}\end{array}$ & $\begin{array}{c}\text { Asia } \\
{[5]}\end{array}$ & $\begin{array}{l}\text { Non-Asia } \\
\text { [6] }\end{array}$ & $\begin{array}{c}\text { LDC } \\
{[7]}\end{array}$ & $\begin{array}{c}\text { Asia } \\
{[8]}\end{array}$ & $\begin{array}{c}\text { Non-Asia } \\
\text { [9] }\end{array}$ \\
\hline \multicolumn{11}{|c|}{ Legal/Inst. Variable: Corruption (CORRUPT) } \\
\hline Financial Openness [t-5] & $(+)$ & $\begin{array}{c}0.0878 \\
{[0.3771]}\end{array}$ & $\begin{array}{c}0.4958 \\
{[1.1722]}\end{array}$ & $\begin{array}{c}0.0764 \\
{[0.3606]}\end{array}$ & $\begin{array}{l}-1.1227 \\
{[1.3328]}\end{array}$ & $\begin{array}{c}-3.857 \\
{[2.7091]}\end{array}$ & $\begin{array}{c}1.227 \\
{[2.1175]}\end{array}$ & $\begin{array}{c}-3.13 \\
{[1.1015]^{* * *}}\end{array}$ & $\begin{array}{c}-4.9713 \\
{[2.3002]^{* *}}\end{array}$ & $\begin{array}{c}-2.7148 \\
{[1.5231]^{*}}\end{array}$ \\
\hline LEVEL: CORRUPT & $(+)$ & $\begin{array}{c}-0.0012 \\
{[0.0091]}\end{array}$ & $\begin{array}{c}0.0527 \\
{[0.0412]}\end{array}$ & $\begin{array}{l}-0.0047 \\
{[0.0092]}\end{array}$ & $\begin{array}{c}0.1382 \\
{[0.0652]^{* *}}\end{array}$ & $\begin{array}{c}0.16 \\
{[0.1197]}\end{array}$ & $\begin{array}{c}0.0599 \\
{[0.0755]}\end{array}$ & $\begin{array}{c}0.0386 \\
{[0.0393]}\end{array}$ & $\begin{array}{c}0.0489 \\
{[0.1074]}\end{array}$ & $\begin{array}{c}0.0545 \\
{[0.0406]}\end{array}$ \\
\hline $\begin{array}{l}\text { INTERACTION: } \\
\text { Corrupt x Fin. Opn. [t-5] }\end{array}$ & $(+)$ & $\begin{array}{c}0.0005 \\
{[0.0071]}\end{array}$ & $\begin{array}{l}-0.0105 \\
{[0.0199]}\end{array}$ & $\begin{array}{c}0.0006 \\
{[0.0070]}\end{array}$ & $\begin{array}{c}0.0308 \\
{[0.0301]}\end{array}$ & $\begin{array}{c}0.1261 \\
{[0.0815]^{13 \%}}\end{array}$ & $\begin{array}{l}-0.0357 \\
{[0.0386]}\end{array}$ & $\begin{array}{c}0.0617 \\
{[0.0208]^{* * *}}\end{array}$ & $\begin{array}{c}0.092 \\
{[0.0513]^{*}}\end{array}$ & $\begin{array}{c}0.0539 \\
{[0.0292]^{*}}\end{array}$ \\
\hline $\mathrm{N}$ & & 289 & 57 & 232 & 101 & 37 & 64 & 115 & 40 & 75 \\
\hline Adj. R-sq. & & 0.09 & -0.01 & 0.10 & 0.23 & 0.26 & 0.16 & 0.16 & 0.23 & 0.12 \\
\hline \multicolumn{11}{|c|}{ Legal/Inst. Variable: Law and order $(L A O)$} \\
\hline Financial Openness [t-5] & $(+)$ & $\begin{array}{c}0.4004 \\
{[0.2904]}\end{array}$ & $\begin{array}{c}0.1669 \\
{[0.6446]}\end{array}$ & $\begin{array}{c}0.4575 \\
{[0.3299]}\end{array}$ & $\begin{array}{c}-2.167 \\
{[1.2516]^{*}}\end{array}$ & $\begin{array}{l}-3.7826 \\
{[3.5459]}\end{array}$ & $\begin{array}{c}-0.3286 \\
{[1.5821]}\end{array}$ & $\begin{array}{c}-2.178 \\
{[1.1883]^{*}}\end{array}$ & $\begin{array}{c}-7.4869 \\
{[2.8449]^{* *}}\end{array}$ & $\begin{array}{l}-0.1451 \\
{[0.8153]}\end{array}$ \\
\hline LEVEL: $L A O$ & $(+)$ & $\begin{array}{c}0.0076 \\
{[0.0087]}\end{array}$ & $\begin{array}{c}0.0545 \\
{[0.0262]^{* *}}\end{array}$ & $\begin{array}{c}-0.004 \\
{[0.0091]}\end{array}$ & $\begin{array}{c}0.0424 \\
{[0.0393]}\end{array}$ & $\begin{array}{c}0.1142 \\
{[0.1030]}\end{array}$ & $\begin{array}{c}-0.0121 \\
{[0.0384]}\end{array}$ & $\begin{array}{c}0.0271 \\
{[0.0316]}\end{array}$ & $\begin{array}{c}0.0603 \\
{[0.1052]}\end{array}$ & $\begin{array}{l}-0.0039 \\
{[0.0210]}\end{array}$ \\
\hline $\begin{array}{l}\text { INTERACTION: } \\
\text { LAO x Fin. Opn. [t-5] }\end{array}$ & $(+)$ & $\begin{array}{c}-0.006 \\
{[0.0056]}\end{array}$ & $\begin{array}{c}-0.008 \\
{[0.0091]}\end{array}$ & $\begin{array}{l}-0.0076 \\
{[0.0062]}\end{array}$ & $\begin{array}{c}0.0433 \\
{[0.0290]}\end{array}$ & $\begin{array}{c}0.0899 \\
{[0.0834]}\end{array}$ & $\begin{array}{l}-0.0087 \\
{[0.0325]}\end{array}$ & $\begin{array}{c}0.0393 \\
{[0.0231]^{*}}\end{array}$ & $\begin{array}{c}0.125 \\
{[0.0581]^{* *}}\end{array}$ & $\begin{array}{c}0.0012 \\
{[0.0155]}\end{array}$ \\
\hline $\mathrm{N}$ & & 289 & 57 & 232 & 101 & 37 & 64 & 115 & 40 & 75 \\
\hline Adj. R-sq. & & 0.09 & 0.02 & 0.10 & 0.20 & 0.14 & 0.13 & 0.12 & 0.24 & 0.02 \\
\hline \multicolumn{11}{|c|}{ Legal/Inst. Variable: Bureaucracy Quality (BQ) } \\
\hline Financial Openness [t-5] & $|(+)|$ & $\begin{array}{c}0.477 \\
{[0.3219]}\end{array}$ & $\begin{array}{c}0.1101 \\
{[1.2406]}\end{array}$ & $\begin{array}{c}0.6222 \\
{[0.3338]^{*}}\end{array}$ & $\begin{array}{c}0.5654 \\
{[1.0655]}\end{array}$ & $\begin{array}{c}0.9428 \\
{[1.9570]}\end{array}$ & $\begin{array}{c}0.264 \\
{[1.7634]}\end{array}$ & $\begin{array}{c}-2.6769 \\
{[1.2885]^{* *}}\end{array}$ & $\begin{array}{l}-2.6124 \\
{[2.9960]}\end{array}$ & $\begin{array}{c}-2.1773 \\
{[1.2338]^{*}}\end{array}$ \\
\hline LEVEL: $B Q$ & $(+)$ & $\begin{array}{c}0.0066 \\
{[0.0088]}\end{array}$ & $\begin{array}{c}0.014 \\
{[0.0236]}\end{array}$ & $\begin{array}{c}-0.0037 \\
{[0.0095]}\end{array}$ & $\begin{array}{c}0.0291 \\
{[0.0503]}\end{array}$ & $\begin{array}{l}-0.0211 \\
{[0.0643]}\end{array}$ & $\begin{array}{c}0.061 \\
{[0.0806]}\end{array}$ & $\begin{array}{c}0.0672 \\
{[0.0387]^{*}}\end{array}$ & $\begin{array}{c}0.0338 \\
{[0.0836]}\end{array}$ & $\begin{array}{c}0.0662 \\
{[0.0361]^{*}}\end{array}$ \\
\hline $\begin{array}{l}\text { INTERACTION: } \\
\text { BQ x Fin. Opn. [t-5] }\end{array}$ & $(+)$ & $\begin{array}{l}-0.0076 \\
{[0.0063]}\end{array}$ & $\begin{array}{c}-0.0034 \\
{[0.0211]}\end{array}$ & $\begin{array}{c}-0.0124 \\
{[0.0069]^{*}}\end{array}$ & $\begin{array}{l}-0.0082 \\
{[0.0205]}\end{array}$ & $\begin{array}{c}-0.0182 \\
{[0.0613]}\end{array}$ & $\begin{array}{c}-0.0135 \\
{[0.0328]}\end{array}$ & $\begin{array}{c}0.0566 \\
{[0.0267]^{* *}}\end{array}$ & $\begin{array}{c}0.0333 \\
{[0.0776]}\end{array}$ & $\begin{array}{c}0.0477 \\
{[0.0243]^{* *}}\end{array}$ \\
\hline $\mathrm{N}$ & & 289 & 57 & 232 & 101 & 37 & 64 & 115 & 40 & 75 \\
\hline Adj. R-sq. & & 0.10 & -0.06 & 0.12 & 0.18 & 0.07 & 0.15 & 0.17 & 0.15 & 0.19 \\
\hline
\end{tabular}

Notes: Point estimates from OLS, heteroskedasticity robust standard errors in parentheses. Dependent variable is the average annual growth rate over a five year period. Financial openness is measured by the Chinn-Ito index (KAOPEN). Regressions include fixed time effects (estimates not reported). Observations of inflation rates in excess of $100 \%$ are dropped from the sample. $(*)[* *]\{* * *\}$ indicates marginal significance at the $(10 \%)[5 \%]\{1 \%\}$ level. 
Table 4: Total effects on the Growth in Stock Market Total Value (\% point) of a one-unit increase in KAOPEN

\begin{tabular}{|c|c|c|c|c|c|c|c|}
\hline & & $\begin{array}{c}\text { Latin } \\
\text { America } \\
\text { [1] }\end{array}$ & $\begin{array}{c}\text { non-Asia } \\
\text { LDC } \\
{[2]}\end{array}$ & $\begin{array}{c}\text { LDC } \\
{[3]}\end{array}$ & $\begin{array}{c}\text { ASIA } \\
\text { [4] }\end{array}$ & $\begin{array}{c}\text { EMG } \\
\text { [5] }\end{array}$ & $\begin{array}{c}\text { Asian } \\
\text { EMG } \\
{[6]} \\
\end{array}$ \\
\hline \multirow{3}{*}{$\begin{array}{l}{[\mathrm{A}]} \\
{[\mathrm{B}]} \\
{[\mathrm{C}]}\end{array}$} & \multirow{3}{*}{$\begin{array}{l}\text { Total effect of KA Openness } \\
\qquad \bar{L} \text { (Legal1) } \\
\text { Threshold level of Legal1 }\end{array}$} & -0.40 & -0.12 & -0.06 & 0.24 & 0.41 & 0.43 \\
\hline & & -1.07 & -0.80 & -0.74 & -0.45 & -0.28 & -0.26 \\
\hline & & \multicolumn{6}{|c|}{-0.68} \\
\hline \multirow{3}{*}{$\begin{array}{l}{[\mathrm{A}]} \\
{[\mathrm{B}]} \\
{[\mathrm{C}]}\end{array}$} & \multirow{3}{*}{$\begin{array}{l}\text { Total effect of KA Openness } \\
\qquad \bar{L} \text { (Corrupt) } \\
\text { Threshold level of Corrupt }\end{array}$} & -0.37 & -0.19 & -0.17 & -0.11 & 0.15 & 0.08 \\
\hline & & 45.95 & 49.04 & 49.27 & 50.32 & 54.73 & 53.54 \\
\hline & & \multicolumn{6}{|c|}{52.2} \\
\hline \multirow{3}{*}{$\begin{array}{l}{[\mathrm{A}]} \\
{[\mathrm{B}]} \\
{[\mathrm{C}]}\end{array}$} & \multirow{3}{*}{$\begin{array}{c}\text { Total effect of KA Openness } \\
\qquad \bar{L} \text { (Law and Order) } \\
\text { Threshold level of } L A O\end{array}$} & -0.27 & -0.18 & -0.15 & -0.00 & 0.05 & 0.09 \\
\hline & & 47.85 & 50.05 & 50.85 & 54.49 & 55.76 & 56.68 \\
\hline & & \multicolumn{6}{|c|}{54.5} \\
\hline \multirow{3}{*}{$\begin{array}{l}\mathrm{A}] \\
{[\mathrm{B}]} \\
{[\mathrm{C}]}\end{array}$} & \multirow{3}{*}{$\begin{array}{c}\text { Total effect of KA Openness } \\
\bar{L} \text { (Bureaucracy Quality) } \\
\text { Threshold level of BQ }\end{array}$} & -0.18 & 0.14 & 0.24 & 0.67 & 0.71 & 0.79 \\
\hline & & 41.61 & 47.07 & 48.66 & 55.87 & 56.44 & 57.91 \\
\hline & & \multicolumn{6}{|c|}{44.7} \\
\hline
\end{tabular}

Notes: "Total Effect" [A] indicates the total effect of a one-unit increase in KAOPEN when the legal/institutional variable takes the value of the average in the subsample group ( $\bar{L}$, shown in [B]). The estimation model is based on equation (1) using the data of the LDC subgroup for the regressions with legal variables (column [7] in Table 3-1). Rows [C] show the threshold level of the legal variable above which the capital account openness has a positive impact on financial development.

Table 5: Correlations between Financial Openness (KAOPEN) and Trade Openness (TRADEOPEN) among different sample groups and decades

\begin{tabular}{c|c|c|c|c}
\hline \multirow{2}{*}{} & \multicolumn{4}{|c}{ Correlations between Financial and Trade Openness } \\
\cline { 2 - 5 } & $1970-2000$ & $1970 \mathrm{~s}$ & $1980 \mathrm{~s}$ & $1990 \mathrm{~s}$ \\
\hline \hline Full & 0.49 & 0.37 & 0.44 & 0.56 \\
IDC & 0.37 & 0.24 & 0.23 & 0.21 \\
LDC & 0.37 & 0.29 & 0.34 & 0.40 \\
EMG & 0.38 & 0.35 & 0.27 & 0.41 \\
Asia & 0.60 & 0.52 & 0.62 & 0.55 \\
Non-Asia LDC & 0.31 & 0.26 & 0.26 & 0.36 \\
Latin America & 0.28 & 0.11 & 0.17 & 0.42 \\
\hline
\end{tabular}


Table 6: Determinants of Capital Account and Trade Openness

LDC, ASIA, and non-Asian LDC: Five year panels, 1980-2000

\begin{tabular}{|c|c|c|c|c|c|c|c|}
\hline \multirow[t]{2}{*}{ Dependent Variable: } & \multicolumn{4}{|c|}{ Financial Openness (t) } & \multicolumn{3}{|c|}{ Trade Openness (t) } \\
\hline & $\begin{array}{c}\text { Pred. } \\
\text { Sign } \\
\end{array}$ & $\begin{array}{c}(1) \\
\text { LDC } \\
\end{array}$ & $\begin{array}{c}(2) \\
\text { Asia } \\
\end{array}$ & $\begin{array}{c}\text { (3) } \\
\text { Non-Asian LDC } \\
\end{array}$ & $\begin{array}{c}(4) \\
\text { LDC } \\
\end{array}$ & $\begin{array}{c}\text { (5) } \\
\text { Asia } \\
\end{array}$ & $\begin{array}{c}\text { (6) } \\
\text { Non-Asian LDC } \\
\end{array}$ \\
\hline Financial Openness $(t-5)$ & + & $\begin{array}{c}0.5582 \\
{[0.0788]^{* * *}}\end{array}$ & $\begin{array}{c}0.5457 \\
{[0.1346]^{* * *}}\end{array}$ & $\begin{array}{c}0.5736 \\
{[0.0998]^{* * *}}\end{array}$ & $\begin{array}{c}0.0019 \\
{[0.0022]}\end{array}$ & $\begin{array}{c}0.0026 \\
{[0.0030]}\end{array}$ & $\begin{array}{c}0.0001 \\
{[0.0025]}\end{array}$ \\
\hline Trade Openness $(t-5)$ & + & $\begin{array}{c}2.0171 \\
{[1.0772]^{* 6 \%}}\end{array}$ & $\begin{array}{c}3.7723 \\
{[2.2915]^{*}}\end{array}$ & $\begin{array}{c}2.4840 \\
{[1.4126]^{*}}\end{array}$ & $\begin{array}{c}0.5633 \\
{[0.0857]^{* * *}}\end{array}$ & $\begin{array}{c}0.7828 \\
{[0.1310]^{* * *}}\end{array}$ & $\begin{array}{c}0.5001 \\
{[0.1032]^{* * *}}\end{array}$ \\
\hline Avg. Budget Surplus $(t-1 \mid t-5)$ & + & $\begin{array}{c}0.0534 \\
{[0.0180]^{* * *}}\end{array}$ & $\begin{array}{c}-0.0674 \\
{[0.0375]^{*}}\end{array}$ & $\begin{array}{c}0.0722 \\
{[0.0196]^{* * *}}\end{array}$ & $\begin{array}{c}0.0002 \\
{[0.0007]}\end{array}$ & $\begin{array}{l}-0.0008 \\
{[0.0014]}\end{array}$ & $\begin{array}{l}-0.0002 \\
{[0.0007]}\end{array}$ \\
\hline Avg. Total reserves $(t-1 \mid t-5)$ & + & $\begin{array}{c}0.0022 \\
{[0.0309]}\end{array}$ & $\begin{array}{c}0.0737 \\
{[0.0683]}\end{array}$ & $\begin{array}{c}-0.0111 \\
{[0.0350]}\end{array}$ & & & \\
\hline Avg. GDP per capita $(t-1 \mid t-5)$ & + & $\begin{array}{c}0.2157 \\
{[0.1169]^{*}}\end{array}$ & $\begin{array}{c}0.6603 \\
{[0.2314]^{* * *}}\end{array}$ & $\begin{array}{c}0.0967 \\
{[0.1392]}\end{array}$ & $\begin{array}{c}0.0196 \\
{[0.0047]^{* * *}}\end{array}$ & $\begin{array}{c}0.0106 \\
{[0.0081]}\end{array}$ & $\begin{array}{c}0.0196 \\
{[0.0058]^{* * *}}\end{array}$ \\
\hline Number of Observations & & 184 & 52 & 129 & 151 & 44 & 107 \\
\hline Adjusted $\mathrm{R}^{2}$ & & 0.44 & 0.67 & 0.35 & 0.63 & 0.79 & 0.58 \\
\hline $\begin{array}{l}\text { Notes: Robust standard errors in } \\
\text { per capita are included at the aver } \\
\text { included in the regression, but the } \\
\text { with the observations excepted fo }\end{array}$ & $\begin{array}{l}\text { rackets. } \\
\text { rage ove } \\
\text { air estim }\end{array}$ & * significant at & $\begin{array}{l}\% \text {; ** significa } \\
\text { constant and re }\end{array}$ & $\begin{array}{l}5 \% \text {; } * * * \text { significal } \\
\text { nal fix effects (time } \\
\text { he regression estima } \\
\text { d. The TRADEOPE }\end{array}$ & $\begin{array}{l}t \text { at } 1 \% \text {. Budget } \\
\text { fixed effects fol } \\
\text { ions are conduc } \\
V \text { variable is inc }\end{array}$ & $\begin{array}{l}\text { rplus, total reser } \\
\text { le Asian sample } \\
\text { d in non-overlap } \\
\text { ded in log form. }\end{array}$ & $\begin{array}{l}\text { ves, and GDP } \\
\text { are also } \\
\text { ping manners }\end{array}$ \\
\hline
\end{tabular}


Table 7: Two-Stage Least Squares Analysis

\section{Instrumented by per capita output, budget balance, and trade openness $\mathbb{\|}$}

LEGAL1 (General Legal/Institutional Development)

LDC, ASIA, and non-Asian LDC: Five year panels, 1980-2000

\begin{tabular}{|c|c|c|c|c|c|c|c|c|c|c|}
\hline & \multirow[b]{2}{*}{$\begin{array}{c}\text { Pred. } \\
\text { sign }\end{array}$} & \multicolumn{3}{|c|}{ Private Credit } & \multicolumn{3}{|c|}{ Stock Market Capitalization } & \multicolumn{3}{|c|}{ Stock Market Total Value } \\
\hline & & $\begin{array}{l}\text { LDC } \\
{[1]}\end{array}$ & $\begin{array}{l}\text { Asia } \\
\text { [2] }\end{array}$ & $\begin{array}{c}\text { Non-Asia } \\
\text { [3] }\end{array}$ & $\begin{array}{l}\text { LDC } \\
{[4]}\end{array}$ & $\begin{array}{c}\text { Asia } \\
{[5]}\end{array}$ & $\begin{array}{c}\text { Non-Asia } \\
\text { [6] }\end{array}$ & $\begin{array}{l}\text { LDC } \\
\text { [7] }\end{array}$ & $\begin{array}{c}\text { Asia } \\
{[8]}\end{array}$ & $\begin{array}{c}\text { Non-Asia } \\
\text { [9] }\end{array}$ \\
\hline \multicolumn{11}{|c|}{ Legal/Inst. Variable: LEGAL1 } \\
\hline Financial Openness [t-5] & $(+)$ & $\begin{array}{c}-0.0033 \\
{[0.3291]}\end{array}$ & $\begin{array}{l}-0.6260 \\
{[0.7949]}\end{array}$ & $\begin{array}{c}0.1150 \\
{[0.6265]}\end{array}$ & $\begin{array}{c}1.8637 \\
{[0.9400]^{* *}}\end{array}$ & $\begin{array}{c}2.8886 \\
{[1.0835]^{* * *}}\end{array}$ & $\begin{array}{c}3.8314 \\
{[2.8627]}\end{array}$ & $\begin{array}{c}2.1115 \\
{[0.7569]^{* * *}}\end{array}$ & $\begin{array}{c}1.3145 \\
{[1.2216]}\end{array}$ & $\begin{array}{c}1.6182 \\
{[1.6016]}\end{array}$ \\
\hline LEVEL: LEGAL1 & $(+)$ & $\begin{array}{l}0.000571 \\
{[0.2504]}\end{array}$ & $\begin{array}{c}1.1015 \\
{[0.8603]}\end{array}$ & $\begin{array}{l}-0.1955 \\
{[0.2722]}\end{array}$ & $\begin{array}{c}2.6474 \\
{[0.9179]^{* * *}}\end{array}$ & $\begin{array}{c}1.9252 \\
{[1.3415]}\end{array}$ & $\begin{array}{c}3.6620 \\
{[2.4412]}\end{array}$ & $\begin{array}{c}1.1623 \\
{[0.5740]^{* *}}\end{array}$ & $\begin{array}{c}2.7263 \\
{[1.0729]^{* *}}\end{array}$ & $\begin{array}{c}1.5867 \\
{[1.3780]}\end{array}$ \\
\hline $\begin{array}{l}\text { INTERACT.: } \\
\text { LEGAL1x Fin. Open. [t-5] }\end{array}$ & $(+)$ & $\begin{array}{l}-0.0305 \\
{[0.1499]}\end{array}$ & $\begin{array}{c}-0.2158 \\
{[0.3634]}\end{array}$ & $\begin{array}{c}-0.0563 \\
{[0.3270]}\end{array}$ & $\begin{array}{c}0.4329 \\
{[0.5091]}\end{array}$ & $\begin{array}{c}1.0339 \\
{[0.6213]^{11 \%}}\end{array}$ & $\begin{array}{c}1.2993 \\
{[1.6665]}\end{array}$ & $\begin{array}{c}1.1257 \\
{[0.3715]^{* * *}}\end{array}$ & $\begin{array}{c}1.0282 \\
{[0.4479]^{* *}}\end{array}$ & $\begin{array}{c}1.2249 \\
{[0.8932]}\end{array}$ \\
\hline Financial Deepening [t-5] & $(-)$ & $\begin{array}{c}0.0257 \\
{[0.0162]}\end{array}$ & $\begin{array}{c}0.0133 \\
{[0.0523]}\end{array}$ & $\begin{array}{c}0.0250 \\
{[0.0135]^{*}}\end{array}$ & $\begin{array}{c}-0.0805 \\
{[0.0326]^{* *}}\end{array}$ & $\begin{array}{c}-0.1052 \\
{[0.0257]^{* * *}}\end{array}$ & $\begin{array}{l}-0.0493 \\
{[0.0597]}\end{array}$ & $\begin{array}{c}-0.1180 \\
{[0.0777]}\end{array}$ & $\begin{array}{c}-0.2430 \\
{[0.0713]^{* * *}}\end{array}$ & $\begin{array}{c}0.1171 \\
{[0.1870]}\end{array}$ \\
\hline Inflation [t-5] & $(-)$ & $\begin{array}{c}-0.005 \\
{[0.0102]}\end{array}$ & $\begin{array}{l}-0.0210 \\
{[0.0584]}\end{array}$ & $\begin{array}{l}-0.0028 \\
{[0.0109]}\end{array}$ & $\begin{array}{c}-0.0508 \\
{[0.0293]^{*}}\end{array}$ & $\begin{array}{c}0.0664 \\
{[0.1854]}\end{array}$ & $\begin{array}{l}-0.0657 \\
{[0.0532]}\end{array}$ & $\begin{array}{c}0.0196 \\
{[0.0319]}\end{array}$ & $\begin{array}{c}0.0343 \\
{[0.1426]}\end{array}$ & $\begin{array}{c}0.0113 \\
{[0.0180]}\end{array}$ \\
\hline $\mathrm{N}$ & & 117 & 35 & 82 & 77 & 31 & 46 & 83 & 32 & 51 \\
\hline R-sq. & & 0.17 & 0.27 & 0.20 & 0.29 & 0.55 & & 0.04 & 0.25 & 0.27 \\
\hline
\end{tabular}

Notes: Point estimates from OLS, heteroskedasticity robust standard errors in parentheses. Dependent variable is the average annual growth rate over a five year period. Financial openness is measured by the Chinn-Ito index (KAOPEN). Regressions include fixed time effects (estimates not reported). Observations of inflation rates in excess of $100 \%$ are dropped from the sample. $\left(^{*}\right)[* *]\{* * *\}$ indicates marginal significance at the (10\%)[5\%]\{1\%\} level.

I - The variable for financial openness lagged five years $\left(K A O P E N_{t-5}\right)$ is instrumented by per capita output and budget balance, both of which are included as the average over the five years prior to five years before each window (i.e., t- 10 through t- 6 since the IV is already lagged five years), regional dummies, and the level of financial openness and trade openness, both of which are lagged ten years. 
Figure 1: Financial Development by Subgroup

(a) Private Credit Creation as \% of GDP

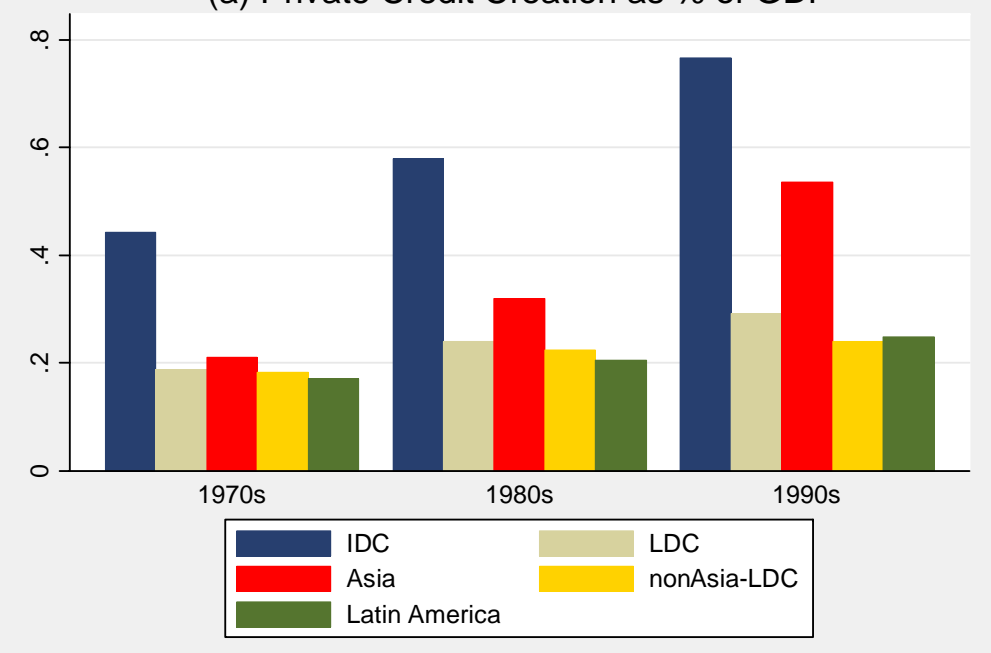

(c) Stock Market Total Value as \% of GDP

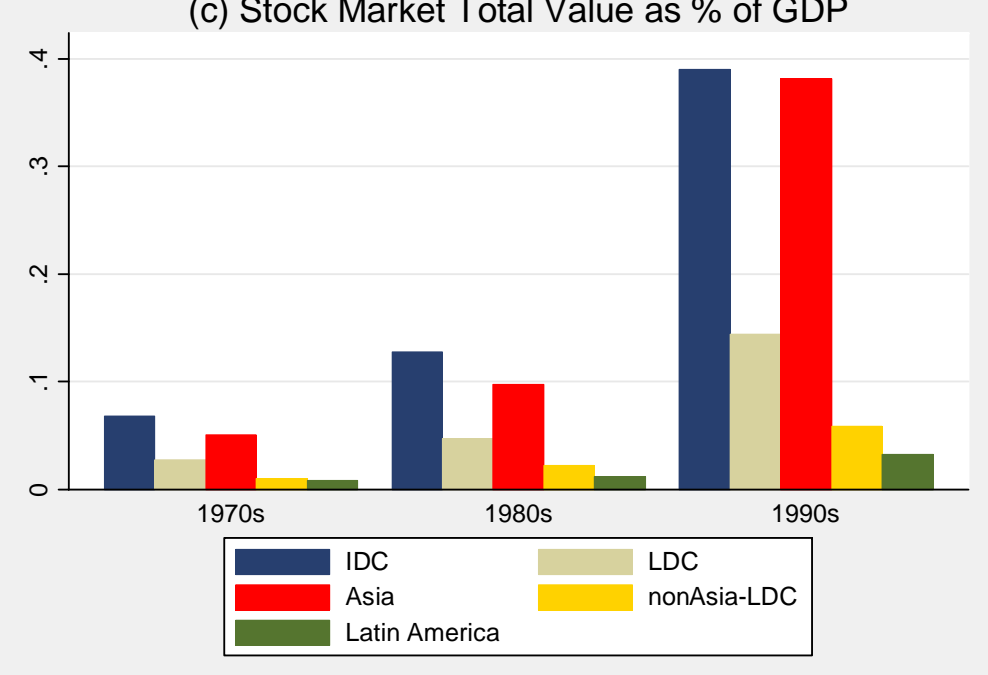

(b) Stock Market Capitalization as \% of GDP

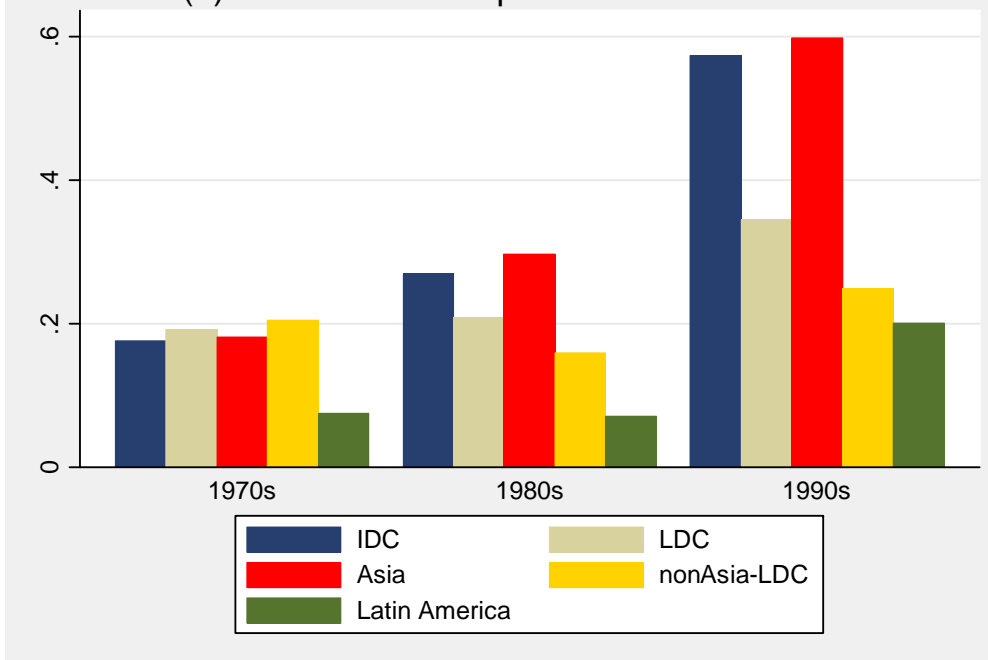

(d) Stock Market Turnover

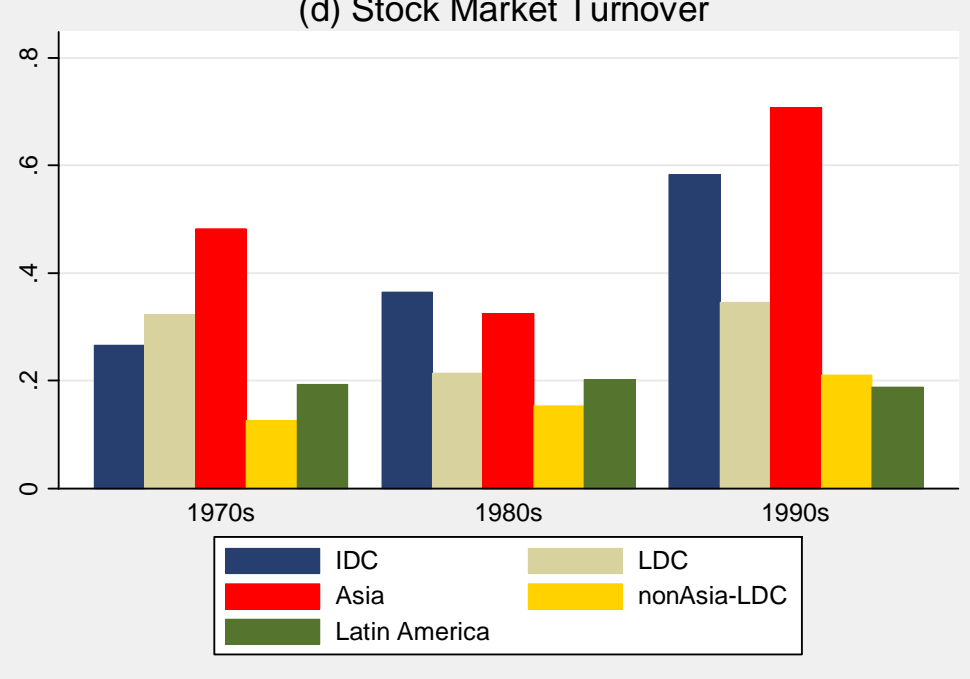


Figure 2: Development of Capital Account Openness, 1970 - 2000:

ASIA, non-Asian LDC, Latin America

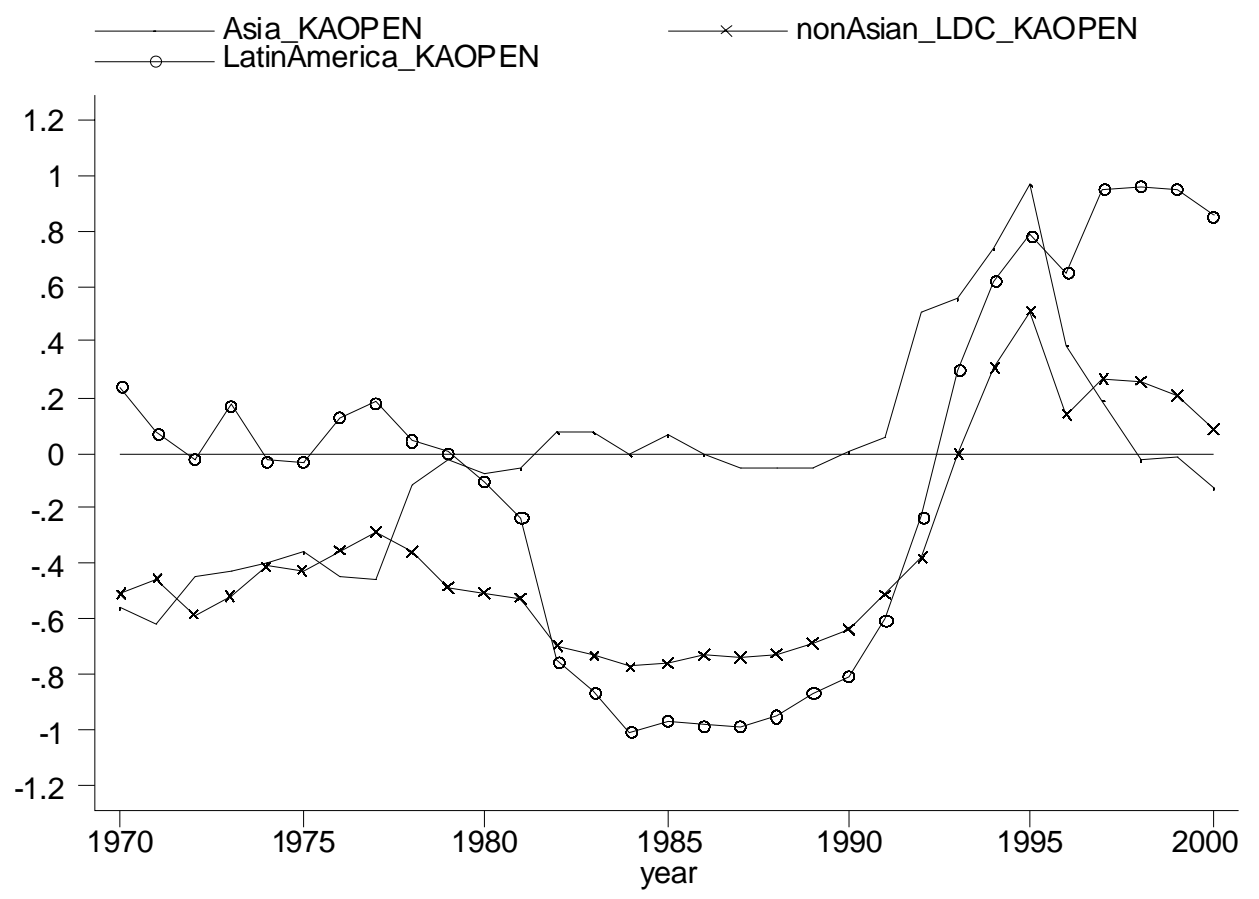

Figure 3: Total Effect of an One-unit Increase in Capital Account Openness (KAOPEN) on Equity Market Development (SMTV)

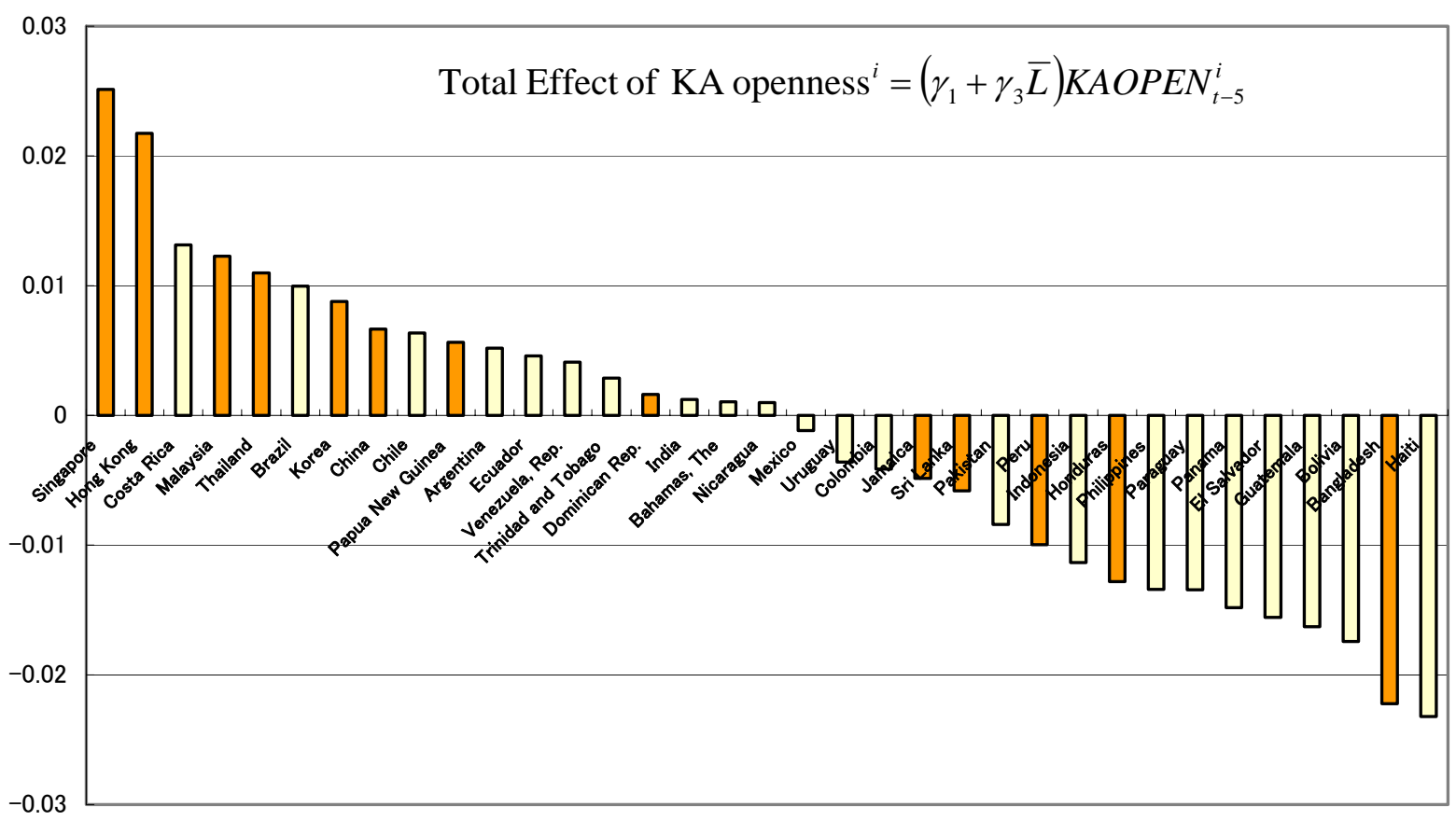

